\title{
Alkali and glycerol pretreatment of West African biomass for production of sugars and ethanol
}

Bensah, Edem C.; Kádár, Zsófia; Mensah, Moses Y.

Published in:

Bioresource Technology Reports

Link to article, DOI:

10.1016/j.biteb.2019.02.013

Publication date:

2019

Document Version

Peer reviewed version

Link back to DTU Orbit

Citation (APA):

Bensah, E. C., Kádár, Z., \& Mensah, M. Y. (2019). Alkali and glycerol pretreatment of West African biomass for production of sugars and ethanol. Bioresource Technology Reports, 6, 123-130.

https://doi.org/10.1016/j.biteb.2019.02.013

\section{General rights}

Copyright and moral rights for the publications made accessible in the public portal are retained by the authors and/or other copyright owners and it is a condition of accessing publications that users recognise and abide by the legal requirements associated with these rights.

- Users may download and print one copy of any publication from the public portal for the purpose of private study or research.

- You may not further distribute the material or use it for any profit-making activity or commercial gain

- You may freely distribute the URL identifying the publication in the public portal

If you believe that this document breaches copyright please contact us providing details, and we will remove access to the work immediately and investigate your claim 


\section{Accepted Manuscript}

Alkali and glycerol pretreatment of West African biomass for production of sugars and ethanol

Edem C. Bensah, Zsófia Kádár, Moses Y. Mensah

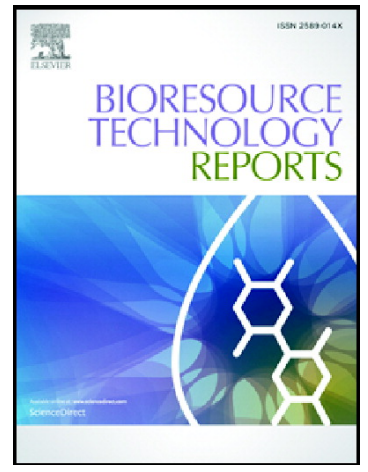

PII: $\quad$ S2589-014X(19)30050-7

DOI: $\quad$ https://doi.org/10.1016/j.biteb.2019.02.013

Reference: $\quad$ BITEB 165

To appear in: $\quad$ Bioresource Technology Reports

Received date: $\quad 4$ January 2019

Revised date: $\quad 18$ February 2019

Accepted date: $\quad 19$ February 2019

Please cite this article as: E.C. Bensah, Z. Kádár and M.Y. Mensah, Alkali and glycerol pretreatment of West African biomass for production of sugars and ethanol, Bioresource Technology Reports, https://doi.org/10.1016/j.biteb.2019.02.013

This is a PDF file of an unedited manuscript that has been accepted for publication. As a service to our customers we are providing this early version of the manuscript. The manuscript will undergo copyediting, typesetting, and review of the resulting proof before it is published in its final form. Please note that during the production process errors may be discovered which could affect the content, and all legal disclaimers that apply to the journal pertain. 


\section{Alkali and glycerol pretreatment of West African biomass for production of sugars and ethanol}

Edem C. Bensah ${ }^{\mathrm{a}, \mathrm{b}, *}$, Zsófia Kádár ${ }^{\mathrm{c}, \mathrm{d}}$, Moses Y. Mensah ${ }^{\mathrm{e}}$

${ }^{a}$ Department of Chemical Engineering, Kumasi Technical University, P. O. Box 854, Kumasi, Ghana;

${ }^{b}$ Centre for Renewable Energy and Energy Efficiency - Kumasi Technical University (CREK), P. O. Box 854, Kumasi, Ghana

${ }^{c}$ Centre for BioProcess Engineering, Department of Chemical and Biochemical Engineering, Technical University of Denmark, Søltofts Plads 229, DK-2800 Kgs. Lyngby, DTU, Denmark

${ }^{d}$ Present affiliation: Section for Sustainable Biotechnology, Department of Chemistry and Bioscience, Aalborg University, A C Mayers Vange 15, 2450 Copenhagen SV, Denmark

${ }^{e}$ Department of Chemical Engineering, Kwame Nkrumah University of Science and Technology (KNUST), Kumasi, Ghana.

*Corresponding author: +233246450842

cudjoe.ebensah@kstu.edu.gh (E.C.Bensah)

\section{Abstract}


$\mathrm{KOH}(1 \%)$ and glycerol (20-40\%) pretreatment of bamboo, rubber, elephant grass and Siam weed were investigated with respect to biomass composition, enzymatic hydrolysis and ethanol fermentation. Delignification was higher under alkaline environment and increased considerably with temperature $\left(25-121{ }^{\circ} \mathrm{C}\right)$. Lignin removal had a positive effect on biomass digestibility, sugars production and ethanol yield. The highest sugar and ethanol yields were observed for $\mathrm{KOH}$ pretreatment $\left(121^{\circ} \mathrm{C}, 1 \mathrm{~h}\right)$ on elephant grass which also recorded the highest delignification $(67.5 \%)$ and consequently the lowest solids recovery (59.5\%). The grass gave the highest yield on glucose (19 $\mathrm{g} / 100 \mathrm{~g}$ raw material), xylose $(8.2 \mathrm{~g} / 100 \mathrm{~g}$ raw material) and ethanol $(9.8 \mathrm{~g} / 100 \mathrm{~g}$ raw material) under $\mathrm{KOH}$ pretreatment $\left(121^{\circ} \mathrm{C}, 1 \mathrm{~h}\right)$. The elephant grass has great potential to be used as a major energy crop in Africa in a biorefinery where production of sugars, ethanol and other valuable biochemicals are optimised.

Key words: $\mathrm{KOH}$ pretreatment; glycerol pretreatment; enzymatic hydrolysis; ethanol; elephant grass

\section{Introduction}

The biofuel industry in Africa is mainly based on ethanol from sugarcane and molasses as well as biodiesel from Jatropha. Lignocellulosic feedstocks such as agricultural and forest residues, grasses and energy crops, and municipal solid waste are known to have promising outcomes though they have not been exploited much (Bensah et al., 2015a). Unlike first generation biofuels, second generation biofuels require advanced processing systems, including additional step for biomass pretreatment. The 
suitability of a pretreatment method is measured by its ability to breakdown recalcitrant lignocellulosic biomass into simpler and fermentable components at low cost, low energy requirement, low inhibitor concentrations, high sugar yield, and less adverse effects on the environment (Bensah and Mensah, 2013). According to Menon and Rao (2012), only few pretreatment methods - including steam explosion, liquid hot water, ammonium fibre explosion (AFEX), lime, and dilute acid applications - have shown promising results at commercial scale. Further, pretreatment such as extrusion, boiling, alkali-based methods (e.g. potassium hydroxide, lime and soaking in aqueous ammonia) and crude glycerol have been identified to possess favourable characteristics for ethanol production even at small-to-moderate scales in Africa (Bensah et al., 2015a; Thomsen et al., 2015; Bensah and Mensah, 2013).

Alkali pretreatment methods possess unique benefits in their ability to remove lignin, thereby exposing cellulose and hemicellulose to enzymatic attack. They are applied at relatively mild conditions and result in reduced sugar degradation (Kim et al., 2016). Bases such as $\mathrm{NaOH}$, lime and aqueous/anhydrous $\mathrm{NH}_{3}$ are more frequently used compared to $\mathrm{KOH}$. Recently, $\mathrm{KOH}$ has received attention among researchers owing to its benign nature and ability to selectively remove and isolate lignin. The black liquor by-product of $\mathrm{KOH}$ pretreatment contains potassium which may find useful applications in soil fertilisation and conditioning, leading to improved economic attractiveness of KOH-based biorefineries (Jaffar et al., 2016; Liu et al., 2015). KOH pretreatment has been applied to biomass such as wheat straw (Tutt et al., 2012a; Liu et al., 2015; Jaffar et al., 2016), rye straw (Tutt et al., 2012b), municipal solid waste (Alqaralleh, 2012), sweet sorghum (Gyalai-Korpos et al., 2008), corn cobs (Wanitwattanarumlug et al., 2012) and switchgrass (Sharma et al., 2013). Concentrations of KOH ranging from 0.5 - 
$9 \% \mathrm{w} / \mathrm{w}$ have been used at temperatures of $20-130{ }^{\circ} \mathrm{C}$. Generally, moderate temperatures $\left(\geq 60{ }^{\circ} \mathrm{C}\right)$ require shorter retention times $(<1 \mathrm{~h})$ for adequate biomass solubility while lower temperatures $\left(25-60^{\circ} \mathrm{C}\right)$ at longer times $(1 \mathrm{~h}-1$ week $)$ favour high sugar and ethanol yields (Gyalai-Korpos et al., 2008).

Like $\mathrm{KOH}$, glycerol is little-known as a solvent for pretreatment of biomass. Glycerol is a by-product of biodiesel production, produced in large quantities and discarded as waste in Africa. However, glycerol can be converted directly to ethanol (Chaudhary et al., 2011) or applied as organic co-solvent in biomass pretreatment (Lynam and Coronella, 2014). Though majority of glycerol pretreatment studies have focused on elevated temperatures $\left(170-400{ }^{\circ} \mathrm{C}\right)$ (Martin et al., 2015; Martín et al., 2011; Romani et al., 2013), their applications at moderate temperatures have not been given much attention.

In this study, $\mathrm{KOH}$ and glycerol pretreatments are applied to four West African biomass - elephant grass, Siam weed, rubber wood and bamboo wood - and their effects on biomass conversion to sugars and ethanol are discussed. The results are benchmarked against a previous study based on hydrothermal pretreatment (Bensah et al., 2015b) at $195{ }^{\circ} \mathrm{C}, 10 \mathrm{~min}$ at $6 \%$ solids loading using a loop reactor.

\section{Materials and methods}

\subsection{Substrate collection and preparation}

Four biomass, namely, rubber wood (Heavea brasiliensis), bamboo wood (Bambusa vulgaris), Siam weed (Chromolaena odorata) and elephant grass (Pennisetum 
purpureum) were studied. Rubber wood (RW) was obtained from Ghana Rubber Estates Limited (Takoradi, Western Region) and green bamboo wood (BW) was harvested at Kumasi Institute for Tropical Agriculture in Ejisu-Juaben municipality of Ghana in July 2014. Elephant grass (EG) and Siam weed (SW) were both obtained from a farm at Dormeabra in May 2015 in the same municipality. Biomass were washed with tap water, cut into pieces $(2-6 \mathrm{~cm})$, sun-dried for a week and stored at room temperature in zip bags until they were studied.

Biomass samples were sized-reduced using a Retsch knife mill fitted with a 2-mm screen. The total solids $(\% \mathrm{w} / \mathrm{w})$ of samples, determined in duplicate using convection oven (NREL, 2008), were as follows: $\mathrm{EG}-90.6 \pm 0$, RW $-90.6 \pm 0, \mathrm{BW}-90.0 \pm 0$, SW $-88.4 \pm 0$. The composition of bamboo wood and rubber wood was known from previous work (Bensah et al., 2015b) while that of elephant grass and Siam weed was determined using the method described under 'compositional analysis.'

\subsection{Pretreatment}

Both $\mathrm{KOH}$ and glycerol pretreatment were carried out in $1 \mathrm{~L}$ Duran bottles using 45 $\mathrm{g}$ dry mass $(\mathrm{DM})$ of biomass $(\leq 2 \mathrm{~mm})$ at solids loading of $6 \% \mathrm{w} / \mathrm{w}$. Pretreatment was performed at room temperature $\left(\sim 25^{\circ} \mathrm{C}\right)$ or at $121{ }^{\circ} \mathrm{C}$ in an autoclave as shown in Table 1. Pretreated biomass were filtered in vacuum and residual solids were washed with at least 3 litres of water. Solids were dried at $60{ }^{\circ} \mathrm{C}$ until the moisture content was less than $8 \%$ after which their composition were determined. The solid fractions were further studied under enzymatic hydrolysis and fermentation as described below. The filtrate was also analysed. 
Table 1

\subsection{Compositional analysis}

Organic-soluble extractives in raw and pretreated samples were removed by extracting biomass with $98 \%$ v/v ethanol for at least 6 hours in a Soxhlet apparatus. The structural composition of extractive-free biomass was determined using strong acid hydrolysis based on laboratory analytical protocol of National Renewable Energy Laboratory (NREL, 2011), with slight modifications previously described by Bensah et al. (2015b). Samples were subjected to sulphuric acid $(72 \% \mathrm{w} / \mathrm{w})$ treatment at $30{ }^{\circ} \mathrm{C}$ for 60 mins in a water bath and subsequently autoclaved in weak sulphuric acid (4\% w/w) at $121{ }^{\circ} \mathrm{C}$ for another 60 mins. The samples were vacuum filtered in porous crucibles and the solid residues were dried to constant weight at $105^{\circ} \mathrm{C}$, and afterwards ashed at $550{ }^{\circ} \mathrm{C}$ for three hours. The filtrate was collected in $50 \mathrm{ml}$ Falcon tubes and analysed for D-glucose, D-xylose and L-arabinose by High Performance Liquid Chromatography (HPLC). The fraction of Klason lignin in samples was determined based on the dried weight of solid residues and weight of ashed materials.

\subsection{Analysis of sugars in pretreatment hydrolysate}

$10 \mathrm{ml}$ of the liquid fraction, containing glucan and pentosan polymers and oligomers, were hydrolysed using equal volume of $8 \% \mathrm{w} / \mathrm{v} \mathrm{H}_{2} \mathrm{SO}_{4}$ at $121{ }^{\circ} \mathrm{C}$ for $10 \mathrm{~min}$ in an autoclave. Samples were transferred to $50 \mathrm{ml}$ Falcon tubes and centrifuged at $4000 \mathrm{rpm}$ 
for 5 minutes. The $\mathrm{pH}$ of the supernatants was reduced to 2-3 with $\mathrm{H}_{2} \mathrm{SO}_{4}$ and $1 \mathrm{ml}$ of the solution was filtered for HPLC analysis as described under analytical methods.

\subsection{Enzymatic hydrolysis of pretreated solid residues}

Raw bamboo and rubber wood were earlier taken through enzymatic hydrolysis and the results are presented by Bensah et al. (2015b). In this study, enzymatic hydrolysis of raw EG and SW as well as pretreated biomass was carried out in triplicate at solids loading of $5 \% \mathrm{w} / \mathrm{w}$ in $50 \mathrm{ml}$ Falcon tubes based on laboratory analytical procedures of NREL (NREL, 2011) with minor modifications. The liquor consisted of $24.62 \mathrm{ml}$ of citric acid buffer (50 mM, pH 5), $0.25 \mathrm{ml}$ of sodium azide (to prevent microbial growth), and cellulase (Novozyme Cellic CTec2) loading of 11.14 Filter Paper Units (FPU)/g TS (0.119 ml/1.25 g TS), supplemented with xylanase (Novozyme Cellic HTec2) at a ratio of 9:1 based on protein loading for all assays. A blank solution (without enzymes) was also prepared for each biomass in triplicate in addition to a control (containing only enzyme solution). Enzymes were kindly donated by Novozymes (Denmark) to Danish Technical University.

The tubes were agitated in a shaker incubator at $50{ }^{\circ} \mathrm{C}$ and $140 \mathrm{rpm}$. After $72 \mathrm{~h}$ of agitation, samples were centrifuged at $4000 \mathrm{rpm}$ for 10 minutes and the $\mathrm{pH}$ of the supernatants was reduced to $2-3$, and further centrifuged for $10 \mathrm{~min}$ at $8000 \mathrm{rpm}$. Finally, $1 \mathrm{ml}$ of supernatants was transferred into vials for HPLC analysis as described below.

\subsection{Inoculum preparation and fermentation}


Saccharomyces cerevisiae (Ethanol Red, Fermentis, France) was grown on sterilised medium containing $50 \mathrm{~g} / \mathrm{L}$ glucose, $2.5 \mathrm{~g} / \mathrm{L}\left(\mathrm{NH}_{4}\right)_{2} \mathrm{SO}_{4}, 2 \mathrm{~g} / \mathrm{L}$ yeast extract, $1 \mathrm{~g} / \mathrm{L}$ $\mathrm{KH}_{2} \mathrm{PO}_{4}$, and $0.3 \mathrm{~g} / \mathrm{L} \mathrm{MgSO}$. The yeast was incubated $\left(30{ }^{\circ} \mathrm{C}, 140 \mathrm{rpm}, 18 \mathrm{~h}\right.$ ) overnight and subsequently used in fermentation at a loading of $2 \% \mathrm{w} / \mathrm{w}(20 \mathrm{mg} / \mathrm{g} \mathrm{DM}$ of sample $)$ or at cell concentration of $2 \mathrm{~g} / \mathrm{L}$, without addition of nutrients. Production of ethanol was carried out at $35^{\circ} \mathrm{C}$ for 144 hours through simultaneous saccharification and fermentation (SSF), preceded by a six-hour prehydrolysis step $\left(50{ }^{\circ} \mathrm{C}\right)$ using cellulase and xylanase at the same loading as was used in enzymatic hydrolysis.

Samples were fermented in triplicate at $10 \%$ total solids and $140 \mathrm{rpm}$ in a shaker incubator using $100 \mathrm{ml}$ Duran bottles. In addition, blank samples containing only fermentation slurry (sodium acetate buffer, $50 \mathrm{mM}, \mathrm{pH} 5$ ) were included in triplicate. The fermentation bottles (fitted with glycerol-filled yeast locks) were weighed regularly to monitor $\mathrm{CO}_{2}$ loss. After $144 \mathrm{~h}, 1 \mathrm{ml}$ samples were diluted with $\mathrm{H}_{2} \mathrm{SO}_{4}$ to $\mathrm{pH}$ of 2-3, centrifuged at $4000 \mathrm{rpm}$ for 5 minutes, and prepared for HPLC analysis for ethanol, sugars, xylitol, and acids.

\subsection{Analytical methods}

Carbohydrates (glucose, xylose and arabinose) in hydrolysates of pretreated samples and the final liquor in enzymatic hydrolysis and fermentation were quantified by HPLC using appropriate standards. The HPLC, which had an organic acid column (BioRad Aminex HPX-87H) and was equipped with a refractive index detector, was operated at $60^{\circ} \mathrm{C}$ with a mobile phase $\left(4 \mathrm{mM} \mathrm{H}_{2} \mathrm{SO}_{4}\right)$ flowrate of $0.6 \mathrm{ml} / \mathrm{min}$. Samples were diluted 
using appropriate volumes of deionised water and filtered using microfilters $(0.2 \mu \mathrm{m}$, $0.4 \mu \mathrm{m})$. The same HPLC conditions were also used for detection of acids generated during enzymatic hydrolysis as well as products of fermentation, including ethanol, xylitol and acids.

\section{Results and discussion}

\subsection{Composition of biomass}

The structural composition of raw biomass used is shown in Table 2. The glucan fractions in both elephant grass (EG) and Siam weed (SW) are lower than respective values (32.0 and 36.2\%) harvested in 2013 (Bensah et al., 2015b). However, the lignin fractions in the current studied biomass were higher, with the fraction in EG being twice as high as the previous one. The significant difference could be attributed to factors such as different times of harvest, different location and soil conditions, and the fact that the earlier harvested-biomass (2013) were at a lower stage of maturity. The glucan fraction in the grass falls on the lower end of the range of values (30.0-41.9\%) reported by other researchers while the lignin fraction was closer to the high end of the range (820.7\%) from literature (Montipo et al., 2018; Santos et al., 2018; Kataria et al., 2017). Regarding bamboo, glucan fraction is higher than those (37.2-48.4\%) obtained by other authors while xylan and lignin fractions are slightly lower (Yuan et al., 2018; Jiang et al., 2016; He et al., 2014; Li et al., 2012). For rubber, the glucan (39.0-49.1) and lignin (13.4-28) fractions reported elsewhere are consistent with the value obtained in the present study, but hemicellulose fraction recorded in this study is considerably lower 
(Chen et al., 2018); Petchpradab et al., 2009). The glucan and hemicellulose fractions in the SW are lower but lignin is higher, relative to results obtained by Zhao et al. (2010).

Table 2

\subsection{Effect of pretreatment on biomass composition}

The composition of the solid fraction of alkali and glycerol pretreated biomass is shown in Tables 3. Under alkali and glycerol pretreatment, glucan fraction in pretreated substrates was lower than those in the raw material for bamboo and rubber for most reaction conditions. For bamboo, the elevated temperature in alkaline environment led to increased dissolution of lignin, hemicelluloses, extractives and ash, culminating in higher glucan fraction. This is affirmed by other authors who applied various pretreatment on bamboo including microwave-KOH (Li et al., 2012) and $\mathrm{NaOH}$ (Yuan et al., 2018; Li et al., 2016).

In contrast, glucan fractions in pretreated EG and SW were largely higher (with respect to the raw material) for all pretreatment conditions. Moreover, the highest glucan fractions (except rubber) were observed for $\mathrm{KOH}$ pretreatment at $121^{\circ} \mathrm{C} / 1 \mathrm{~h}$, with EG having the highest glucan-rich substrate (57\%).

In the alkali media at constant temperature, increasing reaction time from 24 to $48 \mathrm{~h}$ resulted in marginal increase in the glucan component for RW and EG, while an opposite trend was observed for BW and SW. For rubber, the increased reaction time from 24 to $48 \mathrm{~h}$ appears to have caused significant reduction ( $4.8 \%$ difference) in the extractives composition, resulting in an increase in the fractional composition of glucan. 
For glycerol pretreatment, glucan fraction in the solid residue decreased with glycerol concentration for EG and SW, which recorded 1.3 and 3.7 percent drops, respectively. Glucan composition was not affected for bamboo though it increased marginally for rubber. A general observation shows glucan fractions from glycerol pretreated-biomass were lower compared to $\mathrm{KOH}$ pretreatment for biomass studied except SW. Further, glucan fractions were lower relative to respective values obtained from hydrothermal pretreatment of the same biomass (Bensah et al., 2015b) with the exception of bamboo and EG pretreated at $121{ }^{\circ} \mathrm{C} / 1 \mathrm{~h}$ under alkaline environment. Xylan fractions decreased with time under $\mathrm{KOH}$ pretreatment at room temperature for BW, EG and SW, but marginally increased for RW (Tables 2 and 3). With the exception of EG, $\mathrm{KOH}$ pretreatment at $121{ }^{\circ} \mathrm{C}$ yielded the lowest xylan fractions in pretreated solid residues for all other biomass, corroborating the widely observed view that elevated temperatures promote xylose solubilisation. The EG, under $\mathrm{KOH}$ treatment at $121{ }^{\circ} \mathrm{C} / 1 \mathrm{~h}$, recorded the highest xylan fraction (relative to other pretreatment on the grass) at $24.1 \%$ which may be attributed to the high delignification at that condition (see section on biomass delignification). Moreover, the autocatalytic conditions prevalent at high temperatures $\left(\geq 180{ }^{\circ} \mathrm{C}\right)$ that cause rapid removal of hemicellulose sugars are absent at the conditions used in this study; thus, xylan values recorded are lower than those obtained under hydrothermal pretreatment of the same biomass (Bensah et al., 2015b). With regards to glycerol pretreatment, higher glycerol concentration resulted in lower xylan fractions in the pretreated solid residues for all biomass studied, as shown in Table 3.

Lignin fractions in the solid residues for alkali or glycerol pretreated biomass were lower than respective values from hydrothermal pretreatment on the biomass (Bensah et 
al., 2015b). Of the alkaline conditions, lignin composition was lowest at $121{ }^{\circ} \mathrm{C} / 1 \mathrm{~h}$ for all biomass except rubber where there was a marginal increase. The effect of elevated temperature on lignin composition was mostly visible on the pretreated grass which recorded a value of $10.6 \%$ at $121{ }^{\circ} \mathrm{C} / 1 \mathrm{~h}$ compared to $19.5 \%$ for the raw material. Lignin fractions in pretreated samples were higher than respective values in the raw material for all biomass. Moreover, increasing glycerol concentration from 20 to $40 \%$ did not appreciably affect lignin fraction in the pretreated samples.

Table 3

\subsection{Solids recovery after pretreatment}

In general, pretreatment causes biomass components to solubilise in the liquid phase leading to material loss in the solid phase, with the extent of loss dependent on reaction conditions. Solids recovery was determined by dividing the dry mass of pretreated material against that of the raw material. For $\mathrm{KOH}$ pretreatment, solids recovery is influenced significantly by temperature as observed in Fig. 1. The influence of reaction time at constant temperature is however mixed; while the solids recovery of the woody biomass was marginally reduced, that of EG and SW increased as the time was varied from 24 - $48 \mathrm{~h}$, with SW recording the highest percent rise of 5. Overall, solids solubilisation follows the following order: $\mathrm{EG}>\mathrm{SW}>\mathrm{BW}>\mathrm{RW}$, which shows that, EG was the least recalcitrant to fractionation under $\mathrm{KOH}$ pretreatment. This observation is in agreement to the work of Kim et al. (2016) that grasses are more easily fractionated than woody biomass under alkaline pretreatment, since the alkali readily 
cleaves $p$-hydroxyphenyl and syringyl lignins which are dominant in herbaceous biomass. The combined effects of high temperature and alkaline condition caused the solids recovery of EG to fall below $60 \%$, which was significantly lower than values recorded for all other pretreatments of the grass. Similarly, recoveries fell below $60 \%$ when EG was pretreated with sulphuric acid at $121-190^{\circ} \mathrm{C} / 5-30 \mathrm{~min}$, and was mainly attributed to solubilization of hemicellulose and non-structural components (Santos et al., 2018; Montipó et al., 2018).

The minimum solids recovery (74.3) of bamboo, obtained under $\mathrm{KOH}$ pretreatment $\left(121{ }^{\circ} \mathrm{C}\right)$, is about $6.6 \%$ higher than that obtained by Li et al. (2016) using $\mathrm{NaOH}$ $\left(121^{\circ} \mathrm{C}, 1 \mathrm{~h}, 1 \%\right)$ which is similar to conditions used in our study. Expectedly, a minimum recovery of $85.6 \%$ was reported by Yuan et al. (2018) at a lower temperature $\left(100{ }^{\circ} \mathrm{C}\right)$ using $\mathrm{NaOH}$ pretreatment $(4-10 \%, 0.5-3 \mathrm{~h})$ on bamboo.

Unlike the alkali pretreatment, solids recovery exceeded $90 \%$ for all biomass under glycerol application, with recovery in BW (under 20\% glycerol) and EG reaching over 99\% (Fig. 1). It is also observed that solids recovery decreased when glycerol concentration was increased from $20-40 \%$ for the woody biomass but marginally increased for EG and SW.

Fig. 1.

\subsection{Delignification of pretreated biomass}

Alkaline pretreatment effectively disrupts lignin structure resulting in solubilisation, with the degree of dissolution influenced by $\mathrm{pH}$, temperature and reaction time (Kim et 
al., 2016; Bensah and Mensah, 2013). Lignin removal allows hydrolytic enzymes to have easy access to the carbohydrates of the biomass. In this study, delignification (\%) was determined as $L(\%)=100 \times\left(L_{R}-L_{P}\right) / L_{R}$, where $L_{R}$ and $L_{P}$ refer to the dry mass of lignin in raw and pretreated samples, respectively.

Delignification was less than $1 \%$ under $\mathrm{KOH}$ pretreatment at $25^{\circ} \mathrm{C}(24,48 \mathrm{~h})$ for bamboo and rubber. However, at $121{ }^{\circ} \mathrm{C} / 1 \mathrm{~h}$, delignification was $39.3 \%$ on bamboo though it was still low for rubber (5.9\%) and to some extent SW where delignification reached a maximum of $11.6 \%$ at $121{ }^{\circ} \mathrm{C} / 1 \mathrm{~h}$. Lignin removal from $\mathrm{BW}$ is greatly influenced by temperature as opposed to time or concentration; thus, when Juan et al. (2018) applied higher concentrations of $\mathrm{NaOH}(4-10 \%)$ for up to $3 \mathrm{~h}$, the maximum lignin removed was $4.9 \%$. With regards to $\mathrm{SW}$, the percent delignification is close to that $(9.1 \%)$ reported by Zhao et al. (2010) based on $\mathrm{NaOH}$ pretreatment $\left(10 \%, 121{ }^{\circ} \mathrm{C}, 2\right.$ h).

The EG was the most delignified biomass under $\mathrm{KOH}$ pretreatment, recording values of $25.7,33.3$ and $67.5 \%$ for $25{ }^{\circ} \mathrm{C} / 24 \mathrm{~h}, 25{ }^{\circ} \mathrm{C} / 48 \mathrm{~h}$ and $121{ }^{\circ} \mathrm{C} / 1 \mathrm{~h}$, respectively. The results obtained in this study compare well with those observed by Minmunin et al. (2015) where $\mathrm{NaOH}$ pretreatment $\left(70{ }^{\circ} \mathrm{C} / 2 \mathrm{~h}\right)$ of the grass produced lignin removal of 8.7, 20.4 and $51.5 \%$ for aqueous solutions of $0.5,3.0$ and 5.5 wt. $\% \mathrm{NaOH}$, respectively. Lignin removal was ineffective for all biomass under glycerol pretreatment. Moreover, lignin recovery in pretreated substrates exceeded $100 \%$, with maximum value of $112.8 \%$ recorded for rubber in $20 \%$ glycerol solution. Higher than normal lignin recoveries may be attributed to formation of pseudo-lignin (Hu et al., 2012).

\subsection{Degradation products}


Carboxylic acids (lactic, formic, acetic and propionic) formed as a result of degradation of sugars in the hydrolysates of pretreated samples were quantified (Fig. 2). Propionic acid is not shown as it was only detected in a few of the samples at low concentrations, with the highest yield of $0.02 \%$ for bamboo pretreated at $121{ }^{\circ} \mathrm{C}$ in $\mathrm{KOH}$ solution. Under glycerol pretreatment, only acetic acid was significantly detected in the hydrolysates of RW and EG, at $0.24 \pm 0.001$ and $0.27 \pm 0.002 \%$ respectively (data not shown). The effect of temperature on the production of degradation products was most conspicuous for $\mathrm{KOH}$ pretreatment at $121{ }^{\circ} \mathrm{C}$ since it gave the highest acid yields on all biomass studied. In the case of bamboo, acetic acid generation was about one-fourth of values obtained by Li et al.(2012) who studied microwave-KOH (8-12\%) pretreatment of bamboo at $180{ }^{\circ} \mathrm{C}$.

Fig. 2.

\subsection{Enzymatic hydrolysis of pretreated biomass}

Enzymatic hydrolysis (EH) of untreated materials was assessed in our earlier studies (Bensah et al., 2015b) where it was found that the native materials were generally unsuitable since the maximum glucose yield was below $12 \mathrm{~g} / 100 \mathrm{~g}$ of DM in solid fraction. The effect of alkaline and glycerol pretreatment on biomass considered in this work in terms of glucose and xylose yields is shown in Tables 4 and 5, respectively. Alkaline pretreatment removes some amount of lignin and thus loosen the complex biomass structure which results in increased cellulose fractions. However, partial 
delignification does not necessarily lead to high sugar yields since factors such as location, surface area and surface properties of the lignin also play significant roles (Kim et al., 2016).

Table 4

This study shows that increased delignification favours high glucose yields in enzymatic hydrolysis. Of the pretreatment methods and conditions considered for each sample, $\mathrm{KOH}$ pretreatment gave the highest glucose yield at $121{ }^{\circ} \mathrm{C} / 1 \mathrm{~h}$. Further, pretreatment was most effective on the grass which recorded the highest glucose yield of $20.4 \mathrm{~g} / 100 \mathrm{~g}$ of untreated material, representing $47.3 \%$ of the theoretical maximum. This was lower than the yield $(22.2 \mathrm{~g} / 100 \mathrm{~g}$ of untreated DM) obtained under hydrothermal pretreatment $\left(195{ }^{\circ} \mathrm{C}, 10 \mathrm{~min}\right)$ in an earlier study under the same hydrolysis conditions (Bensah et al., 2015b), but higher than that (24.8 g/100 g DM of pretreated material or $19.3 \mathrm{~g} / 100 \mathrm{~g}$ DM of raw material) obtained by Scholl et al. (2015) based on steam explosion $\left(190{ }^{\circ} \mathrm{C} / 10 \mathrm{~min}\right)$ of EG under $48 \mathrm{~h}$ of enzymatic hydrolysis using enzyme loading of $10 \mathrm{FPU} / \mathrm{g}$ DM and solids loading of $4 \% \mathrm{w} / \mathrm{v}$. In another study, Li et al. (2015) obtained cellulose-to-glucose conversion of at least 55\% from dilute acid pretreated EG cultivars, using a low enzyme loading of 7 FPU/g DM. Kataria and coworkers (2017) also obtained 55\% conversion on steam explosion $\left(161{ }^{\circ} \mathrm{C}, 11.5 \mathrm{~min}\right)$ of acid-soaked EG using $20 \mathrm{FPU} / \mathrm{g}$ in $96 \mathrm{~h}$ of saccharification while a higher yield of $76 \%$ (glucose + cellobiose) was reported based on sulphuric acid pretreatment $\left(121{ }^{\circ} \mathrm{C}\right.$, $30 \mathrm{~min}$ ), with $20 \mathrm{FPU} / \mathrm{g}$ and $15 \mathrm{U} / \mathrm{g} \beta$-glucosidase (Santos et al., 2018). 
In general, longer pretreatment and/or higher temperatures correlated positively with glucose yields. The effect of temperature was however the deciding factor as observed in glucose yield increase of about three times for bamboo, one and half times for RW and SW, and one and quarter times for EG, compared with pretreatment condition producing the second highest sugar yield for each biomass. The elevated temperature also led to higher delignification of all samples under alkaline conditions which was favourable to enzymatic saccharification. Between the two woody samples, RW gave higher sugar yields (at least three-quarters higher) under alkaline conditions at $25{ }^{\circ} \mathrm{C}$. However, at $121{ }^{\circ} \mathrm{C}, \mathrm{BW}$ recorded sugar yield of $16.8 \mathrm{~g} / 100 \mathrm{~g}$ (36.9\% conversion) which was marginally higher than that for RW. The glucose yield of bamboo was found superior to result obtained by Li et al. (2012) who measured $21 \%$ conversion using microwave-KOH pretreatment of bamboo, but inferior by nearly two-thirds of glucose yield of $\mathrm{NaOH}$ pretreated bamboo (Jiang et al., 2016). Bamboo is a woody grass that contains p-hydroxyl, guaiacyl, and syringyl that is typical of hardwood lignin found in materials like RW, nonetheless it was less prone to releasing sugars at mild conditions. Therefore, when Jiang et al. (2016) applied ultra-high pressure in addition to $\mathrm{NaOH}$, as high as $87.3 \%$ conversion was attained. Another two-stage pretreatment involving $\mathrm{NaOH}\left(8 \%, 100{ }^{\circ} \mathrm{C}, 3 \mathrm{~h}\right)$ and $\mathrm{H}_{2} \mathrm{O}_{2}(6 \%)$ gave about $95 \%$ cellulose conversion (as opposed to about $38 \%$ using only $\mathrm{NaOH}$ ) at $18 \mathrm{FPU} / \mathrm{g}$ cellulose in $72 \mathrm{~h}$ (Yuan et al., 2018).

Only few studies on conversion of rubber wood to sugars have been cited in literature. A study by Petchpradab et al. (2009) using autoclave pretreatment (130-240 ${ }^{\circ} \mathrm{C}$ ) gave maximum glucan conversion of $8 \%$ using enzyme loading of 0.3 units $/ \mathrm{mg}$ solid, lower than values obtained under $\mathrm{KOH}$ pretreatment in this study. A lower yield 
than this study was also reported by Nazarpour et al. (2013) based on fungi pretreatment of rubber.

Contrary to $\mathrm{KOH}$ pretreatment, glycerol application was ineffective in releasing glucose from biomass studied at the conditions considered in this work. An objective of this study was to ascertain whether glycerol pretreatment at moderate temperatures and times could produce sugars at rates that make it economically possible to implement low-tech plants in African countries using glycerol from biodiesel plants. However, glycerol pretreatment at mild conditions is unfavourable perhaps due to the high boiling point and the low basicity of glycerol, and as such higher temperatures $\left(\geq 180{ }^{\circ} \mathrm{C}\right)$ are thus required. This observation confirms the work of Lynam and Coronella (2014) where glycerol-pretreated of rice hulls at $110^{\circ} \mathrm{C}$ failed to release glucose in enzymatic hydrolysis. In contrast, high cellulose to glucose conversion of $98 \%$ was realised by Romaní et al. (2013) on Eucalyptus wood pretreated at $200{ }^{\circ} \mathrm{C} / 69 \mathrm{~min}$ in glycerol solution (56\%) using enzyme load of $20 \mathrm{FPU} / \mathrm{g}$ solid.

In terms of increasing glucose yields under alkaline and glycerol pretreatment, the following order can be gleaned from Table 4: $\mathrm{SW}<\mathrm{RW}<\mathrm{RW}<\mathrm{EG}$, meaning $\mathrm{SW}$ is the most recalcitrant while EG is the least resistant to fractionation and enzymatic action. As corroborated by other authors (e.g. Zhao et al., 2010), SW is more difficult to fractionate than other herbaceous plants; nonetheless, total reducing sugar conversion $(28.8 \%)$ obtained under this study $\left(\mathrm{KOH}, 121^{\circ} \mathrm{C}\right)$ was over $5 \%$ point greater than values reported by the authors under $\mathrm{NaOH}$ and mild acid pretreatments.

Among pretreatment options used, xylose yields were highest for samples pretreated with $\mathrm{KOH}$ at $121^{\circ} \mathrm{C} / 1 \mathrm{~h}$ as shown in Table 5. Though xylan to xylose conversion was higher for BW (58.6\%) compared to EG (57.2\%), the grass gave a higher yield of 
xylose $(10.8 \mathrm{~g} / 100 \mathrm{~g}$ of untreated material) because it had a bigger xylan fraction in the native material. The yield from EG was more than three times higher than that obtained by Scholl et al. (2015) at $3 \mathrm{~g} / 100 \mathrm{~g}$ under steam pretreatment $\left(190{ }^{\circ} \mathrm{C} / 10 \mathrm{~min}\right)$ but lower than the result from Bensah et al. (2015b) by a third under hydrothermal pretreatment. As shown in Table 5, glycerol pretreated samples under the conditions used were generally inferior to those from $\mathrm{KOH}$ pretreatment in releasing xylose under enzymatic hydrolysis.

Table 5

\subsection{Fermentation}

SSF of the solid fraction of pretreated substrates was performed at $32{ }^{\circ} \mathrm{C}$ at solids loading of $6 \% \mathrm{w} / \mathrm{w}$ and yeast concentration of $2 \mathrm{~g} / \mathrm{L}$ (or $2 \mathrm{~g} / 100 \mathrm{~g}$ DM of sample). No nutrients were added. Fig. 3 gives the mass percentage of products detected in the fermentation liquor. Glucose was fully consumed in the liquor (data not shown), signifying efficient conversion to ethanol. On the other hand, xylose conversion was poor and could be attributed to inability of yeast to convert C5 sugars to ethanol. Xylose concentrations were relatively high in all $\mathrm{KOH}$-pretreated samples $\left(121^{\circ} \mathrm{C} / 1 \mathrm{~h}\right)$, with elephant grass recording the highest at $14.94 \%$. Xylose and other hemicelluloses in waste fermentation broth may be converted into useful biochemicals such as lactic acid (in addition to lactic acid from the liquor) to improve overall economics (Zhang et al., 2014). 
Of the carboxylic acids, formic acid was most noticeable especially on glycerol pretreated samples where values ranged from 2.89 to $6.63 \%$. The grass gave the highest yield of xylitol at 3.64\% for $\mathrm{KOH}$-pretreated samples $\left(121{ }^{\circ} \mathrm{C} / 1 \mathrm{~h}\right)$ while those pretreated at room temperature generated considerable quantities of lactic acid at an average of $4.33 \%$. Acetic acid and propanoic acid were generally low $(<1 \%)$ in the final fermented liquor (data not shown).

Fig. 3.

The final ethanol concentration, conversion efficiency and yield are shown in Table 6. The final ethanol yield is based on the dry mass of the original untreated biomass. The results show that ethanol concentration, conversion efficiency and yield from the alkali pretreatment were considerably higher than those from glycerol pretreated substrates, likely as a result of the failure of glycerol solution to cause biomass fractionation under the moderate conditions used in this study. Under alkaline conditions, the greatest effect on ethanol production for each biomass occurred under pretreatment at $121{ }^{\circ} \mathrm{C}$. The grass recorded the highest ethanol yield of $9.8 \mathrm{~g} / 100 \mathrm{~g}$ of dry untreated material in alkaline pretreatment at $121{ }^{\circ} \mathrm{C}$ which is comparable to the value $(10.1 \mathrm{~g} / 100 \mathrm{~g}$ DM) realised under hydrothermal pretreatment in a different study (Bensah et al., 2015b). Further, ethanol yield (16.4 g/100 g pretreated mass) from EG is found higher than the maximum yield $(107.7 \mu \mathrm{L} / \mathrm{g}$ of pretreated $\mathrm{EG})$ obtained by Scholl et al. (2015) which by our calculation is equivalent to $7.1 \mathrm{~g}$ ethanol/100 $\mathrm{g}$ raw EG. Further, the effect of increasing pretreatment time from 24 to $48 \mathrm{~h}$ at room temperature was not felt as far as ethanol yields are concerned. In another study, the ethanol yield of 
elephant grass ranged from $0.11-0.29 \mathrm{~g} / 100 \mathrm{~g}$ at solids loading of $4-20 \%$, with separate fermentation performed for $48 \mathrm{~h}$ on samples that had been concomitantly ball-milled and hydrolysed at $10 \mathrm{FPU} / \mathrm{g}$ (Menegol et al., 2016). A high yield, representing $74.6 \%$ of the theoretical maximum, was obtained by Montipo et al. (2018) based on fermentation of steam-exploded EG at 20\% solids loading and enzyme dosage of 20 FPU/g sample.

$\mathrm{KOH}$ pretreatment at ambient conditions as well as glycerol pretreatment at moderate temperatures produced lower ethanol concentrations $(<5 \mathrm{~g} / \mathrm{L})$ on BW, RW and SW. But, ethanol concentration exceeding $5 \mathrm{~g} / \mathrm{L}$ was realised for the grass at room temperature under $\mathrm{KOH}$ application, suggesting the need to do further investigating at longer pretreatment times. Overall, ethanol yields and conversion in decreasing order for the samples follows the order EG $>\mathrm{RW}>\mathrm{BW}>\mathrm{SW}$. The results indicate Siam weed was the least amenable to fractionation under the pretreatment conditions studied, suggesting harsher conditions such as longer times, higher temperatures and higher $\mathrm{KOH}$ or glycerol concentrations may be more suitable. Two-stage pretreatments under mild conditions appear to give high ethanol yields for recalcitrant biomass such as bamboo (Yuan et al., 2018).

Clearly, the EG possesses the greatest potential among the materials studied and at the conditions considered as it gave the highest yield of ethanol, $9.8 \mathrm{~g} / 100 \mathrm{~g}$ of untreated EG, at a final concentration of $16.4 \mathrm{~g} / \mathrm{L}$. This was achieved at solids and glucan loading of 10.0 and $6.1 \%$, respectively.

Table 6

\section{Conclusions}


$\mathrm{KOH}-$ pretreated bamboo wood, rubber wood, elephant grass and Siam weed gave higher delignification compared to glycerol-pretreated samples, with delignification increasing significantly with pretreatment temperature $\left(25,121^{\circ} \mathrm{C}\right) . \mathrm{KOH}$ pretreatment at $121{ }^{\circ} \mathrm{C} / 1 \mathrm{~h}$ on elephant grass gave the lowest solids recovery $(59.5 \%)$ and highest delignification (67.5\%), and consequently produced the highest sugar (27.2 g glucose and xylose /100 g of raw material) and ethanol yields (9.8 g/100 g raw material). Higher glucose $(\geq 35 \%$ theoretical maximum) and xylose ( $\geq 52 \%$ theoretical maximum) yields were also observed for bamboo and rubber compared to Siam weed for $\mathrm{KOH}$ pretreatment at $121{ }^{\circ} \mathrm{C} / 1 \mathrm{~h}$.

\section{Acknowledgements}

This work was supported by DANIDA Fellowship Centre (DFC journal no. 10018RISØ). Ingelis Larsen is appreciated for providing technical support to the authors.

\section{References}

Alqaralleh, R.M., 2012. Effect of alkaline pretreatment on anaerobic digestion of organic fraction of municipal solid waste. MSc thesis: Department of Civil Engineering, University of Ottawa. http://citeseerx.ist.psu.edu/viewdoc/download?doi=10.1.1.865.6645\&rep=rep1\&typ e=pdf, 06/18.

Bensah, E.C., Kemausuor, F., Miezah, K., Kádár, Z., Mensah, M., 2015a. African 
perspective on cellulosic ethanol production. Renew. Sust. Energ. Rev. 49, 1-11. https://doi.org/10.1016/j.rser.2015.04.059.

Bensah, E.C., Kádár, K., Mensah, Y.M., 2015b. Ethanol production from hydrothermally-treated biomass from West Africa. BioResources 10(4), 65226537. DOI: 10.15376/biores.10.4.6522-6537.

Bensah, E.C., Mensah, M., 2013. Chemical pretreatment methods for the production of cellulosic ethanol: technologies and innovations. International Journal of Chemical Engineering, Article ID 719607. http://dx.doi.org/10.1155/2013/719607.

Chaudhary, N., Ngadi, M.O., Simpson, B.K., Kassama, L.S., 2011. Biosynthesis of ethanol and hydrogen by glycerol fermentation using Escherichia coli. Adv. Chem. Engineer. Sci. 1(3), 83-89. http://dx.doi.org/10.4236/aces.2011.13014.

Chen, W.-H., Wang, C.-W., Kumar, G., Rousset, P., Hsieh, T.-H., 2018. Effect of torrefaction pretreatment on the pyrolysis of rubber wood sawdust analyzed by PyGC/MS. Bioresour. Technol. 259, 469-473. https://doi.org/10.1016/j.biortech.2018.03.033.

Gyalai-Korpos, M., Feczák, K., Réczey, K., 2008. Sweet sorghum juice and bagasse as a possible feedstock for bioethanol production. Hung. J. Ind. Chem, VESZPRÉM $36(1-2), 43-48$.

He, M.-x., Wang, J.-1., Qin, H., Shui, Z.-x., Zhu, Q.-1., Wu, B., Tan, F.-r., Pan, K., Hu, Q.-c., Dai, L.-c., Wang, W.-g., Tang, X.-y., Hu, G.Q., 2014. Bamboo: A new source of carbohydrate for biorefinery. Carbohydr. Polym. 111, 645-654. https://doi.org/10.1016/j.carbpol.2014.05.025.

Hu, F., Jung, S., Ragauskas, A., 2012. Pseudo-lignin formation and its impact on enzymatic hydrolysis. Bioresour. Technol. 117, 7-12. 
https://doi.org/10.1016/j.biortech.2012.04.037.

Jaffar, M., Pang, Y., Yuan, H., Zou, D., Liu Y., Zhu B., Korai, R.M., Li, X., 2016. Wheat straw pretreatment with $\mathrm{KOH}$ for enhancing biomethane production and fertilizer value in anaerobic digestion. Chin. J. Chem. Eng. 24(3), 404-409. https://doi.org/10.1016/j.cjche.2015.11.005.

Jiang, Z., Fei, B., Li, Z., 2016. Pretreatment of bamboo by ultra-high pressure explosion with a high-pressure homogenizer for enzymatic hydrolysis and ethanol fermentation. Bioresour. Technol. 214, 876-880. https://doi.org/10.1016/j.biortech.2016.05.025.

Kataria, R., Mol, A., Schulten, E., Happel, A., Mussatto, S.I., 2017. Bench scale steam explosion pretreatment of acid impregnated elephant grass biomass and its impacts on biomass composition, structure and hydrolysis. Ind. Crop. Prod. 106, 48-58. https://doi.org/10.1016/j.indcrop.2016.08.050.

Kim, J.S., Lee, Y.Y., Kim, T.H., 2016. A review on alkaline pretreatment technology for bioconversion of lignocellulosic biomass. Bioresour. Technol. 199, 42-48. https://doi.org/10.1016/j.biortech.2015.08.085.

Li, Y., Zhang, Y., Zheng, H., Du, J., Zhang, H., Wu, J., Huang, H., 2015. Preliminary evaluation of five elephant grass cultivars harvested at different time for sugar production. Chin. J. Chem. Eng. 23, 1188-1193.

https://doi.org/10.1016/j.cjche.2015.04.016.

Li, Z., Jiang, Z., Fei, B., Yu, Y., Cai, Z., 2012. Effective of microwave-KOH pretreatment on enzymatic hydrolysis of bamboo. Journal of Sustainable Bioenergy Systems 2, 104-107. http://dx.doi.org/10.4236/jsbs.2012.24015.

Li, K., Wan, J., Wang, X., Wang, J., Zhang, J., 2016. Comparison of dilute acid and 
alkali pretreatments in production of fermentable sugars from bamboo: Effect of Tween 80. Ind. Crop. Prod. 83, 414-422.

https://doi.org/10.1016/j.indcrop.2016.01.003.

Liu, X., Zicari, S.M., Liu, G., Li, Y., Zhang, R., 2015. Pretreatment of wheat straw with potassium hydroxide for increasing enzymatic and microbial degradability. Bioresour. Technol. 185, 150-157. https://doi.org/10.1016/j.biortech.2015.02.047.

Lynam, J.G., Coronella, C.J., 2014. Glycerol as an ionic liquid co-solvent for pretreatment of rice hulls to enhance glucose and xylose yield. Bioresour. Technol. 166, 471-478. https://doi.org/10.1016/j.biortech.2014.05.086.

Martín, C., Volkov, P.V., Rozhkova, A.M., Puls, J., Sinitsyn, A.P., 2015. Comparative study of the enzymatic convertibility of glycerol- and dilute acid-pretreated sugarcane bagasse using Penicillium- and Trichoderma-based cellulase preparations. Ind. Crop. Prod. 77, 382-390. http://dx.doi.org/10.1016/j.indcrop.2015.09.015.

Martín, C., Puls, J., Saake, B., Schreiber, A., 2011. Effect of glycerol pretreatment on component recovery and enzymatic hydrolysis of sugarcane bagasse. Cellul. Chem. Technol. 45(7-8), 487-494.

Menegol, D., Fontana, R.C., Dillon, A.J.P., Camassola, M., 2016. Second-generation ethanol production from elephant grass at high total solids. Bioresour. Technol. 211, 280-290. https://doi.org/10.1016/j.biortech.2016.03.098.

Menon, V., Rao, M., 2012. Trends in bioconversion of lignocellulose: biofuels, platform chemicals \& biorefinery concept. Prog. Energy Combust. Sci. 38(4), 522-550. https://doi.org/10.1016/j.pecs.2012.02.002. 
Minmunin, J., Limpitipanich, P., Promwungkwa, A., 2015. Delignification of elephant grass for production of cellulosic intermediate. Energy Procedia 79, 220-225. https://doi.org/10.1016/j.egypro.2015.11.468.

Montipó, S., Ballesteros, I., Fontana, R.C., Liu, S., Martins, A.F., Ballesteros, M., Camassola, M., 2018. Integrated production of second generation ethanol and lactic acid from steam-exploded elephant grass. Bioresour. Technol. 249, 1017-1024. https://doi.org/10.1016/j.biortech.2017.11.001.

Nazarpour, F., Abdullah, D.K., Abdullah, N., Zamiri, R., 2013. Evaluation of biological pretreatment of rubberwood with white rot fungi for enzymatic hydrolysis. Materials 6, 2059-2073. https://doi.org/10.3390/ma6052059.

Petchpradab, P., Yoshida, T., Charinpanitkul, T., Matsumura, Y., 2009. Hydrothermal pretreatment of rubber wood for the saccharification process. Ind. Eng. Chem. Res. 48, 4587-4591. https://pubs.acs.org/doi/abs/10.1021/ie801314h.

NREL, 2008. Preparation of samples for compositional analysis. Laboratory analytical procedure, Technical report NREL/TP-510-42620. https://www.nrel.gov/docs/gen/fy08/42620.pdf, 09/13.

NREL, 2011. Determination of structural carbohydrates and lignin in biomass. Laboratory analytical procedure, Technical report NREL/TP-510-42618. https://www.nrel.gov/docs/gen/fy13/42618.pdf, 09/13

Romaní, A., Ruiz, H.A., Pereira, F.B., Domingues, L., Teixeira, J.A., 2013. Fractionation of Eucalyptus globulus wood by glycerol-water pretreatment: Optimization and modelling. Ind. Eng. Chem. Res. 52(40), 14342-14352. https://pubs.acs.org/doi/abs/10.1021/ie402177f. 
Santos, C.C., de Souza, W., Sant' Anna, C., Brienzo, M., 2018. Elephant grass leaves have lower recalcitrance to acid pretreatment than stems, with higher potential for ethanol production. Ind. Crop. Prod. 111, 193-200.

https://doi.org/10.1016/j.indcrop.2017.10.013.

Scholl, A.L., Menegol, D., Pitarelo, A.P., Fontana, R.C., Filho, A.Z., Ramos, L.P., Dillon, A.J., Camassola, M., 2015. Ethanol production from sugars obtained during enzymatic hydrolysis of elephant grass (Pennisetum purpureum, Schum.) pretreated by steam explosion. Bioresour. Technol. 192, 228-237. https://doi.org/10.1016/j.biortech.2015.05.065.

Sharma, R., Palled, V., Sharma-Shivappa, R.R., Osborne, J., 2013. Potential of potassium hydroxide pretreatment of switchgrass for fermentable sugar production. Appl. Biochem. Biotechnol. 169,761-772. https://doi.org/10.1007/s12010-0120009-x.

Thomsen, S.T., Londoño, J.E.G., Schmidt, J.E., Kádár, Z., 2015. Comparison of different pretreatment strategies for ethanol production of West African biomass, Appl. Biochem. Biotechnol. 175, 2589-2601. https://doi.org/10.1007/s12010-0141444-7.

Tutt, M., Kikas T., Olt J., 2012a. Influence of different pretreatment methods on bioethanol production from wheat straw. Agronomy Research Biosystem Engineering 1, 269-276.

Tutt, M., Kikas T., Olt J., 2012b. Comparison of different pretreatment methods on degradation of rye straw. Engineering for Rural Development; Jelgava 24 (25), 412416.

Wanitwattanarumlug, B., Luengnaruemitchai, A., Wongkasemjit, S., 2012. 
Characterization of corn cobs from microwave and potassium hydroxide pretreatment. World Academy of Science, Engineering \& Technology 6 (4).

Yuan, Z., Wen, Y., Kapu, N.S., 2018. Ethanol production from bamboo using mild alkaline pre-extraction followed by alkaline hydrogen peroxide pretreatment, Bioresour. Technol. 247, 242-249. https://doi.org/10.1016/j.biortech.2017.09.080.

Zhang, L., You, T., Zhang, L., Li, M., Xu, F., 2014. Comprehensive utilization of waste hemicelluloses during ethanol production to increase lactic acid yield: from pretreatment to fermentation. Biotechnol. Biofuels 7:494. https://doi.org/10.1186/s13068-014-0189-4.

Zhao, X., Zhang, L., Liu, D., 2010. Pretreatment of Siam weed stem by several chemical methods for increasing the enzymatic digestibility. Biotechnol. J. 5, 493504. https://doi.org/10.1002/biot.200900284. 

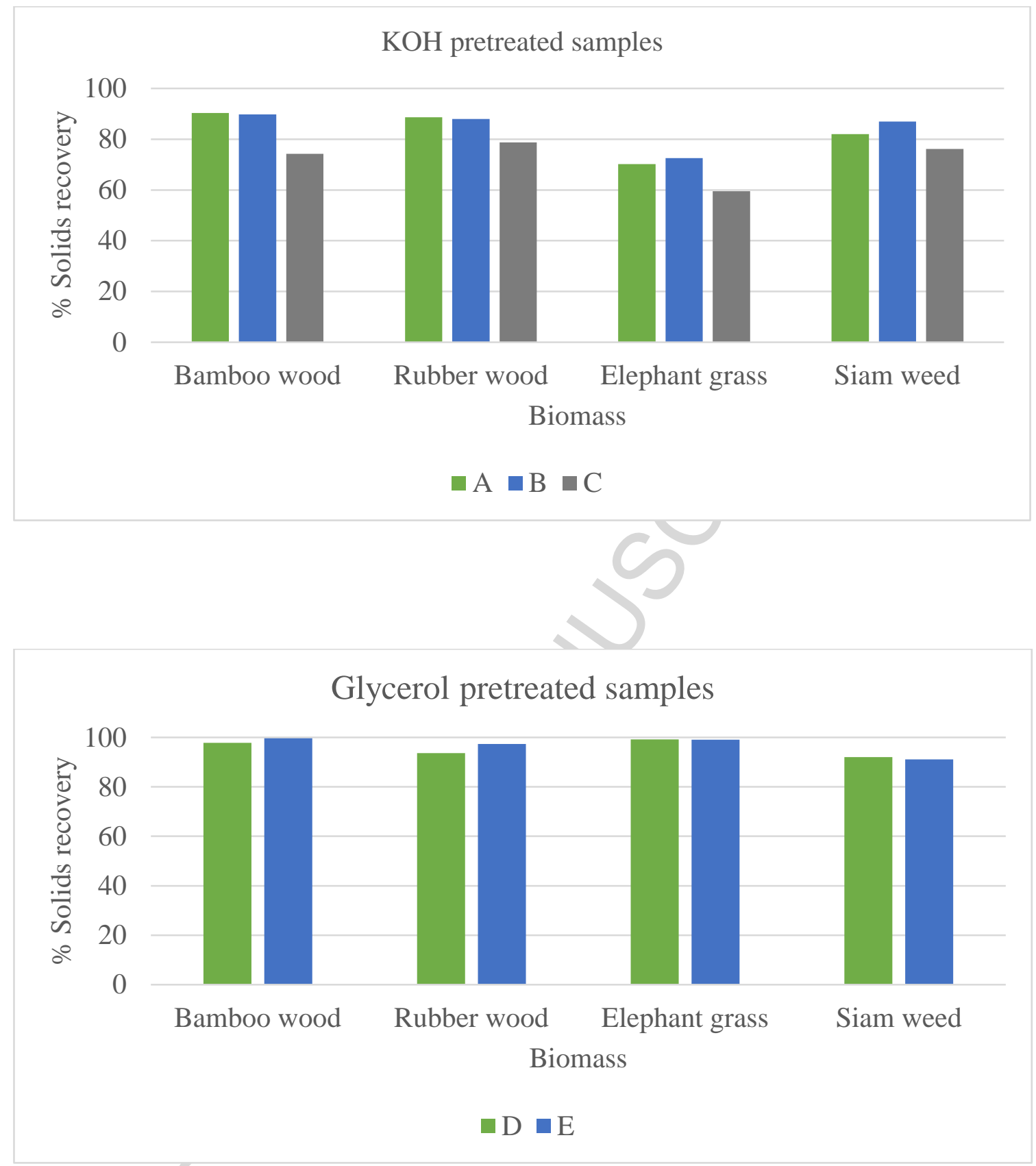

Fig. 1. Solids recovery after pretreatment of biomass samples

Recovery is obtained as grams of solids in hydrolysate after pretreatment per gram of dry biomass before pretreatment. A - KOH$/ 25{ }^{\circ} \mathrm{C} / 24 \mathrm{~h}, \mathrm{~B}-\mathrm{KOH} / 25^{\circ} \mathrm{C} / 48 \mathrm{~h}, \mathrm{C}-$ $\mathrm{KOH} / 121{ }^{\circ} \mathrm{C} / 1 \mathrm{~h}, \mathrm{D}-\operatorname{glycerol}(20 \%) / 121{ }^{\circ} \mathrm{C}, \mathrm{E}-\operatorname{glycerol}(40 \%) / 121{ }^{\circ} \mathrm{C} / 1 \mathrm{~h}$. 

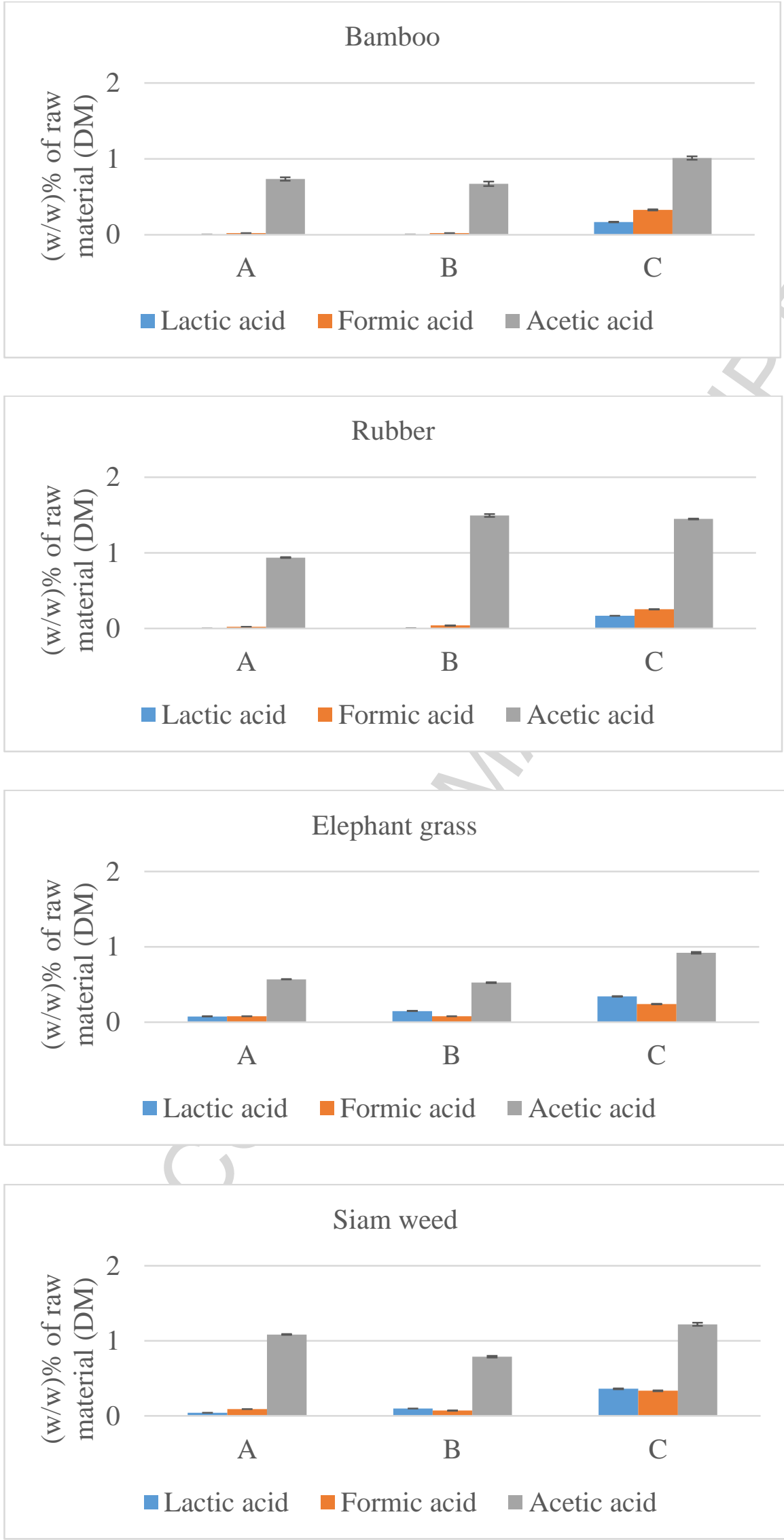

Fig. 2. Carboxylic acids in hydrolysates of $\mathrm{KOH}$ pretreated samples 
Conditions: A $\left(25{ }^{\circ} \mathrm{C}, 24 \mathrm{~h}\right), \mathrm{B}\left(25^{\circ} \mathrm{C}, 48 \mathrm{~h}\right)$ and $\mathrm{C}\left(121{ }^{\circ} \mathrm{C}, 1 \mathrm{~h}\right)$. 

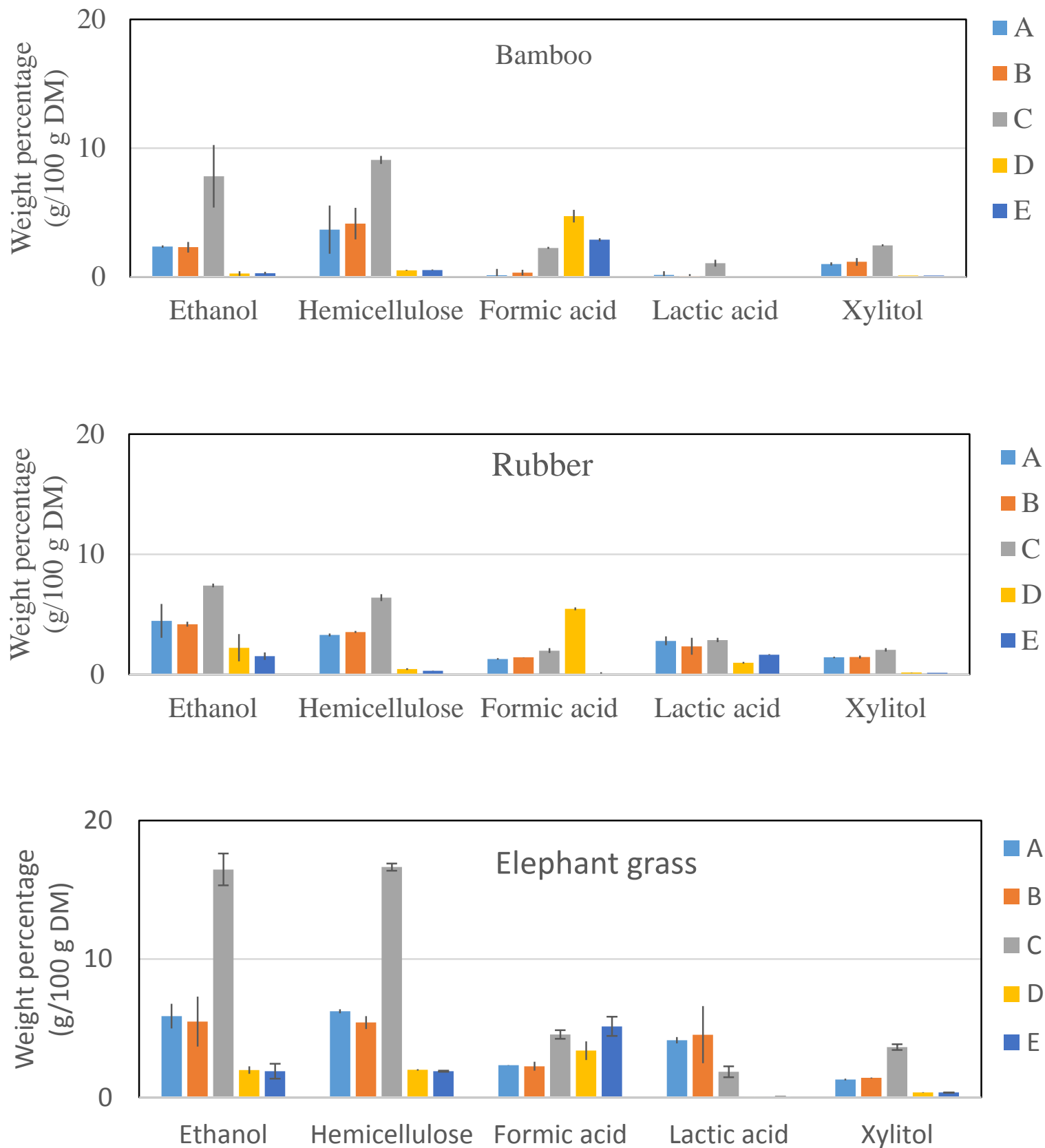


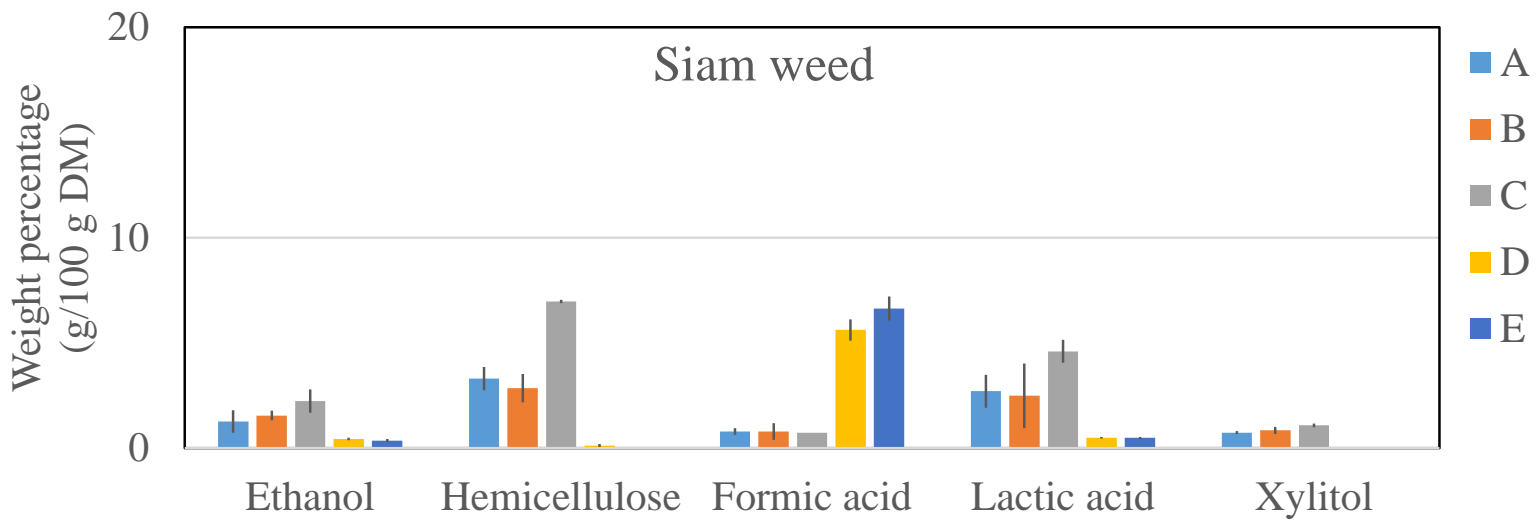

$\mathrm{A}-\mathrm{KOH} / 25{ }^{\circ} \mathrm{C} / 24 \mathrm{~h}, \mathrm{~B}-\mathrm{KOH} / 25^{\circ} \mathrm{C} / 48 \mathrm{~h}, \mathrm{C}-\mathrm{KOH} / 121{ }^{\circ} \mathrm{C} / 1 \mathrm{~h}, \mathrm{D}-$ glycerol $(20 \%) / 121{ }^{\circ} \mathrm{C}, \mathrm{E}-$ glycerol $(40 \%) / 121{ }^{\circ} \mathrm{C} / 1 \mathrm{~h}$.

Fig. 3. Weight percentage (g/100 g DM) of hemicellulose and fermentation products after $144 \mathrm{~h}$ of SSF.

Hemicellulose comprises xylose and arabinose. Error bars show standard deviations from mean values. 
Table 1

Pretreatment conditions

\begin{tabular}{llll}
\hline Pretreatment & $\begin{array}{l}\text { Concentration of KOH or } \\
\text { glycerol in pretreatment } \\
\text { liquor }(\% \mathrm{w} / \mathrm{w})\end{array}$ & $\begin{array}{l}\text { Temperature, } \\
\left({ }^{\circ} \mathrm{C}\right)\end{array}$ & $\begin{array}{l}\text { Reaction } \\
\text { time }(\mathrm{h})\end{array}$ \\
\hline $\mathrm{KOH}$ & 1 & $\sim 25$ & 24 \\
$\mathrm{~A}$ & 1 & $\sim 25$ & 48 \\
$\mathrm{~B}$ & 1 & 121 & 1 \\
$\mathrm{C}$ & & & \\
Glycerol & 20 & 121 & 1 \\
D & 40 & 121 & 1 \\
E & & & \\
\hline
\end{tabular}


Table 2

Composition of raw bamboo and rubber wood (\% dry weight)

\begin{tabular}{cccccccc}
\hline Biomass & Glucan & Xylan & Arabinan & $\begin{array}{c}\text { Klason } \\
\text { lignin }\end{array}$ & Extractives & Ash & Sum \\
\hline EG & $29.8 \pm$ & $14.0 \pm$ & $1.9 \pm 0.6$ & $\begin{array}{c}19.5 \pm \\
\text { (19.5 }\end{array}$ & 18.1 & $4.3 \pm 0.1$ & 87.6 \\
& 0.3 & 0.6 & & 0.7 & & & \\
$\mathrm{SW}$ & $28.5 \pm$ & $13.7 \pm$ & $1.3 \pm 0$ & $24.7 \pm$ & 14.5 & $1.6 \pm 0.1$ & 84.3 \\
& 0.5 & 0.1 & & 0.6 & & & \\
$\mathrm{BW}^{\mathrm{a}}$ & $49.8 \pm$ & $17.9 \pm$ & $0.8 \pm 0$ & $23.5 \pm$ & 7.1 & $1.5 \pm 0$ & 100.6 \\
& 0.3 & 0.3 & & 0.5 & & & \\
$\mathrm{RW}^{\mathrm{a}}$ & $43.5 \pm$ & $15.0 \pm$ & $0.3 \pm 0$ & $20.2 \pm$ & 6.5 & $0.9 \pm 0$ & 86.4 \\
& 2.4 & 0.3 & & 0.4 & & & \\
\hline
\end{tabular}

EG - elephant grass, SW - Siam weed, BW - bamboo wood, and RW - rubber wood;

${ }^{\text {a }}$ Source: Bensah et al. (2015b). 
Table 3

Composition of solid fraction of samples after pretreatment

\begin{tabular}{|c|c|c|c|c|c|c|c|c|c|}
\hline $\begin{array}{l}\text { Biomas } \\
\mathrm{s}\end{array}$ & $\begin{array}{l}\text { Pretreat } \\
\text { ment }\end{array}$ & $\begin{array}{l}\text { Conditions } \\
,{ }^{\circ} \mathrm{C} / \mathrm{h}\end{array}$ & Glucan & Xylan & Arabinan & $\begin{array}{l}\text { Klason } \\
\text { lignin }\end{array}$ & $\begin{array}{l}\text { Extrac } \\
\text { tives }\end{array}$ & Ash & Sum \\
\hline \multirow[t]{6}{*}{$\begin{array}{l}\text { Bambo } \\
\text { o }\end{array}$} & $\mathrm{KOH}$ & $25 / 24$ & $\begin{array}{l}44.1 \pm \\
0.4\end{array}$ & $\begin{array}{l}19.2 \pm \\
0.5\end{array}$ & $1.8 \pm 0.2$ & $\begin{array}{l}26.8 \pm \\
0.6\end{array}$ & 3.7 & $\begin{array}{l}2.8 \pm \\
0.1\end{array}$ & 98.3 \\
\hline & $\mathrm{KOH}$ & $25 / 48$ & $\begin{array}{l}43.2 \pm \\
0.5\end{array}$ & $\begin{array}{l}18.2 \pm \\
0.1\end{array}$ & $1.8 \pm 0.1$ & $\begin{array}{l}25.7 \pm \\
0.3\end{array}$ & 2.6 & $2.5 \pm 0$ & 94.0 \\
\hline & $\mathrm{KOH}$ & $121 / 1$ & $\begin{array}{l}53.1 \pm \\
0.2\end{array}$ & $\begin{array}{l}17.8 \pm \\
0.1\end{array}$ & $1.2 \pm 0$ & $\begin{array}{l}19.2 \pm \\
1.5\end{array}$ & 1.1 & $1.6 \pm 0$ & 94.0 \\
\hline & G20 & $121 / 1$ & $\begin{array}{l}40.7 \pm \\
1.5\end{array}$ & $\begin{array}{l}18.4 \pm \\
0.1\end{array}$ & $1.5 \pm 0.1$ & $\begin{array}{l}26.1 \pm \\
0.8\end{array}$ & 4.8 & $0.7 \pm 0$ & 92.2 \\
\hline & G40 & $121 / 1$ & $\begin{array}{l}40.9 \pm \\
2.2\end{array}$ & $\begin{array}{l}18.2 \pm \\
1.1\end{array}$ & $1.5 \pm 0.2$ & $\begin{array}{l}26.6 \pm \\
1.1\end{array}$ & 3.6 & $\begin{array}{l}0.6 \pm \\
0.1\end{array}$ & 91.4 \\
\hline & \multicolumn{2}{|c|}{ Raw bamboo ${ }^{a}$} & $\begin{array}{l}49.8 \pm \\
0.3\end{array}$ & $\begin{array}{l}17.9 \pm \\
0.3\end{array}$ & $0.8 \pm 0$ & $\begin{array}{l}23.5 \pm \\
0.5\end{array}$ & 7.1 & $1.5 \pm 0$ & $\begin{array}{l}100 . \\
6\end{array}$ \\
\hline \multirow[t]{6}{*}{ Rubber } & $\mathrm{KOH}$ & $25 / 24$ & $\begin{array}{l}41.7 \pm \\
0.6\end{array}$ & $\begin{array}{l}16.1 \pm \\
0.2\end{array}$ & $1.0 \pm 0.2$ & $\begin{array}{l}23.0 \pm \\
0.6\end{array}$ & 5.8 & $\begin{array}{l}2.9 \pm \\
0.2\end{array}$ & 90.6 \\
\hline & $\mathrm{KOH}$ & $25 / 48$ & $\begin{array}{l}43.9 \pm \\
0.4\end{array}$ & $\begin{array}{l}16.4 \pm \\
0.5\end{array}$ & $0.8 \pm 0.1$ & $\begin{array}{l}25.7 \pm \\
0.4\end{array}$ & 1.0 & $\begin{array}{l}2.6 \pm \\
0.2\end{array}$ & 90.4 \\
\hline & $\mathrm{KOH}$ & $121 / 1$ & $\begin{array}{l}43.4 \pm \\
1.2\end{array}$ & $\begin{array}{l}13.1 \pm \\
0.4\end{array}$ & $0.4 \pm 0$ & $\begin{array}{l}24.1 \pm \\
0.6\end{array}$ & 3.0 & $\begin{array}{l}3.1 \pm \\
0.2\end{array}$ & 87.2 \\
\hline & $\mathrm{G} 20$ & $121 / 1$ & $30.0 \pm 0$ & $\begin{array}{l}14.3 \pm \\
2.1\end{array}$ & $0.9 \pm 0.2$ & $\begin{array}{l}23.4 \pm \\
1.3\end{array}$ & 6.9 & $\begin{array}{l}0.6 \pm \\
0.1\end{array}$ & 76.1 \\
\hline & G40 & $121 / 1$ & $\begin{array}{l}31.0 \pm \\
2.1\end{array}$ & $\begin{array}{l}12.7 \pm \\
0\end{array}$ & $0.8 \pm 0.2$ & $\begin{array}{l}18.4 \pm \\
0.7\end{array}$ & 13.3 & $\begin{array}{l}0.2 \pm \\
0.1\end{array}$ & 76.3 \\
\hline & \multicolumn{2}{|c|}{ Raw rubber ${ }^{\mathrm{a}}$} & $\begin{array}{l}43.5 \pm \\
2.4\end{array}$ & $\begin{array}{l}15.0 \pm \\
0.3\end{array}$ & $0.3 \pm 0$ & $\begin{array}{l}20.2 \pm \\
0.4\end{array}$ & 6.5 & $0.9 \pm 0$ & 86.4 \\
\hline \multirow[t]{6}{*}{ EG } & $\mathrm{KOH}$ & $25 / 24$ & $\begin{array}{l}42.9 \pm \\
0.2\end{array}$ & $\begin{array}{l}20.2 \pm \\
0.1\end{array}$ & $3.0 \pm 0.2$ & $\begin{array}{l}20.6 \pm \\
0.9\end{array}$ & 3.2 & $\begin{array}{l}3.1 \pm \\
0.1\end{array}$ & 93.1 \\
\hline & $\mathrm{KOH}$ & $25 / 48$ & $\begin{array}{l}43.3 \pm \\
0\end{array}$ & $\begin{array}{l}19.5 \pm \\
0\end{array}$ & $3.5 \pm 0$ & $\begin{array}{l}17.9 \pm \\
1.2\end{array}$ & 5.2 & $\begin{array}{l}5.4 \pm \\
0.3\end{array}$ & 94.8 \\
\hline & $\mathrm{KOH}$ & $121 / 1$ & $\begin{array}{l}60.6 \pm \\
0.6\end{array}$ & $\begin{array}{l}24.1 \pm \\
0\end{array}$ & $2.5 \pm 0.1$ & $\begin{array}{l}10.6 \pm \\
0\end{array}$ & 0 & $\begin{array}{l}2.5 \pm \\
0.2\end{array}$ & $\begin{array}{l}100 . \\
3\end{array}$ \\
\hline & G20 & $121 / 1$ & $\begin{array}{l}37.7 \pm \\
1.4\end{array}$ & $\begin{array}{l}19.3 \pm \\
0.7\end{array}$ & $2.4 \pm 0.1$ & $\begin{array}{l}22.0 \pm \\
0.7\end{array}$ & 8.3 & $\begin{array}{l}2.1 \pm \\
0.1\end{array}$ & 91.9 \\
\hline & G40 & $121 / 1$ & $\begin{array}{l}36.4 \pm \\
1.4\end{array}$ & $\begin{array}{l}17.8 \pm \\
0.7\end{array}$ & $2.5 \pm 0.1$ & $\begin{array}{l}21.6 \pm \\
1.0\end{array}$ & 8.3 & $\begin{array}{l}1.9 \pm \\
0.1\end{array}$ & 88.4 \\
\hline & Raw EG & & $\begin{array}{l}29.8 \pm \\
0.3\end{array}$ & $\begin{array}{l}14.0 \pm \\
0.6\end{array}$ & $1.9 \pm 0.6$ & $\begin{array}{l}19.5 \pm \\
0.7\end{array}$ & 18.1 & $\begin{array}{l}4.3 \pm \\
0.1\end{array}$ & 87.7 \\
\hline \multirow[t]{3}{*}{$\begin{array}{l}\text { Siam } \\
\text { weed }\end{array}$} & $\mathrm{KOH}$ & $25 / 24$ & $\begin{array}{l}36.1 \pm \\
0\end{array}$ & $\begin{array}{l}16.4 \pm \\
0.1\end{array}$ & $1.1 \pm 0.1$ & $\begin{array}{l}29.7 \pm \\
1.5\end{array}$ & 1.7 & $3.0 \pm 0$ & 87.9 \\
\hline & $\mathrm{KOH}$ & $25 / 48$ & $\begin{array}{l}35.0 \pm \\
1.1\end{array}$ & $\begin{array}{l}15.5 \pm \\
0.4\end{array}$ & $1.1 \pm 0.2$ & $\begin{array}{l}29.6 \pm \\
0.4\end{array}$ & 4.4 & $\begin{array}{l}3.3 \pm \\
0.3\end{array}$ & 88.8 \\
\hline & $\mathrm{KOH}$ & $121 / 1$ & $\begin{array}{l}39.5 \pm \\
1.7\end{array}$ & $\begin{array}{l}15.5 \pm \\
0.1\end{array}$ & $0.7 \pm 0.1$ & $\begin{array}{l}28.6 \pm \\
0.8\end{array}$ & 5.3 & $\begin{array}{l}4.5 \pm \\
0.1\end{array}$ & 94.1 \\
\hline
\end{tabular}




\begin{tabular}{lllllllll} 
G20 & $121 / 1$ & $36.3 \pm$ & $17.4 \pm$ & $1.4 \pm 0.1$ & $27.6 \pm$ & 7.6 & $1.0 \pm$ & 91.3 \\
& & 2.4 & 1.1 & & 0.8 & & 0.3 & \\
G40 & $121 / 1$ & $32.6 \pm$ & $15.6 \pm$ & $1.3 \pm 0.1$ & $27.9 \pm$ & 6.1 & $0.9 \pm$ & 84.5 \\
& & 0.6 & 0.1 & & 1.1 & & 0.1 & \\
\multirow{2}{*}{ Raw SW } & $28.5 \pm$ & $13.7 \pm$ & $1.3 \pm 0$ & $24.7 \pm$ & 14.5 & $1.6 \pm$ & 84.3 \\
& & 0.5 & 0.1 & & 0.6 & & 0.1 & \\
\hline
\end{tabular}

G20 - glycerol (20\% w/w), G40 - glycerol (40\% w/w), ${ }^{\mathrm{a}}$ Source: Bensah et al. (2015b). 
Table 4

Glucose yield and conversion after pretreatment and enzymatic hydrolysis

\begin{tabular}{|c|c|c|c|}
\hline Pretreatment & $\begin{array}{l}\text { Glucose released, } \\
\mathrm{g} / 100 \mathrm{~g} \text { DM of } \\
\text { pretreated solids }\end{array}$ & $\begin{array}{l}\text { Glucose yield, } \\
\mathrm{g} / 100 \mathrm{~g} \mathrm{DM} \text { of } \\
\text { untreated material }\end{array}$ & $\begin{array}{l}\text { Glucose conversion, } \\
\% \text { theoretical } \\
\text { maximum }\end{array}$ \\
\hline \multicolumn{4}{|l|}{ Bamboo } \\
\hline A & $6.2 \pm 0.2$ & 5.6 & 12.6 \\
\hline B & $6.4 \pm 0.3$ & 5.8 & 13.4 \\
\hline $\mathrm{C}$ & $21.8 \pm 1.6$ & 16.2 & 36.9 \\
\hline D & $0.8 \pm 0.1$ & 0.8 & 1.7 \\
\hline $\mathrm{E}$ & $0.8 \pm 0$ & 0.8 & 1.8 \\
\hline \multicolumn{4}{|l|}{ Rubber } \\
\hline A & $11.5 \pm 1.9$ & 10.2 & 24.7 \\
\hline B & $11.0 \pm 1.2$ & 9.7 & 22.5 \\
\hline $\mathrm{C}$ & $17.2 \pm 1.6$ & 13.6 & 35.7 \\
\hline D & $7.3 \pm 2.2$ & 7.2 & 22.1 \\
\hline $\mathrm{E}$ & $7.8 \pm 0.2$ & 7.3 & 22.7 \\
\hline \multicolumn{4}{|c|}{ Elephant grass } \\
\hline A & $17.3 \pm 0.3$ & 12.2 & 36.3 \\
\hline B & $18.8 \pm 1.0$ & 13.6 & 39.0 \\
\hline $\mathrm{C}$ & $31.9 \pm 1.4$ & 19.0 & 47.3 \\
\hline $\mathrm{D}$ & $6.0 \pm 0.1$ & 6.0 & 14.4 \\
\hline $\mathrm{E}$ & $5.6 \pm 0.7$ & 5.5 & 13.8 \\
\hline \multicolumn{4}{|l|}{ Siam weed } \\
\hline A & $5.4 \pm 0.3$ & 4.5 & 13.6 \\
\hline B & $5.8 \pm 0.5$ & 5.0 & 14.9 \\
\hline $\mathrm{C}$ & $10.5 \pm 0.5$ & 8.0 & 24.0 \\
\hline $\mathrm{D}$ & $1.1 \pm 0.1$ & 1.0 & 2.6 \\
\hline $\mathrm{E}$ & $0.9 \pm 0.1$ & 0.8 & 2.5 \\
\hline
\end{tabular}

$\mathrm{A}-\mathrm{KOH} / 25^{\circ} \mathrm{C} / 24 \mathrm{~h}, \mathrm{~B}-\mathrm{KOH} / 25^{\circ} \mathrm{C} / 48 \mathrm{~h}, \mathrm{C}-\mathrm{KOH} / 121{ }^{\circ} \mathrm{C} / 1 \mathrm{~h}, \mathrm{D}-$ glycerol $(20 \%) / 121{ }^{\circ} \mathrm{C}, \mathrm{E}-$ glycerol $(40 \%) / 121{ }^{\circ} \mathrm{C} / 1 \mathrm{~h}$. Glucose released is expressed as $\mathrm{g}$ glucose per $100 \mathrm{~g}$ DM of the solid fraction of pretreated samples after enzymatic hydrolysis. Glucose yield is given as g glucose per $100 \mathrm{~g}$ DM of untreated samples after enzymatic hydrolysis. Cellulose conversion to glucose is expressed as g glucose released in enzymatic hydrolysis per $100 \mathrm{~g}$ cellulose in pretreated solids, multiplied by the hydration factor of glucose (0.9). 
Table 5

Xylose yield and conversion after pretreatment and enzymatic hydrolysis

\begin{tabular}{llll}
\hline Pretreatment & $\begin{array}{l}\text { Xylose released, } \\
\text { g/100 g DM in } \\
\text { pretreated solids }\end{array}$ & $\begin{array}{l}\text { Xylose yield, } \\
\text { g/100 g DM of } \\
\text { untreated material }\end{array}$ & $\begin{array}{l}\text { Xylose conversion, } \\
\text { \% theoretical } \\
\text { maximum }\end{array}$ \\
\hline Bamboo & & & \\
A & $4.3 \pm 0$ & 3.9 & 22.5 \\
B & $4.5 \pm 0$ & 4.1 & 24.9 \\
C & $10.5 \pm 0.4$ & 7.8 & 58.6 \\
D & $0.2 \pm 0$ & 0.2 & 1.3 \\
E & $0.3 \pm 0$ & 0.3 & 1.4 \\
Rubber & & & \\
A & $4.1 \pm 0.2$ & 3.7 & 25.6 \\
B & $4.1 \pm 0.1$ & 3.7 & 25.3 \\
C & $7.0 \pm 0.3$ & 5.5 & 52.9 \\
D & $0.4 \pm 0.1$ & 0.4 & 3.1 \\
E & $0.4 \pm 0$ & 0.4 & 2.8 \\
Elephant grass & & & 35.3 \\
A & $7.1 \pm 0.1$ & 5.0 & 41.1 \\
B & $8.0 \pm 0.2$ & 5.8 & 57.2 \\
C & $13.8 \pm 0.4$ & 8.2 & 6.2 \\
D & $1.2 \pm 0$ & 1.2 & 5.6 \\
E & $1.0 \pm 0.1$ & 1.0 & 29.0 \\
Siam weed & & & 32.0 \\
A & $4.8 \pm 0.1$ & 3.9 & 46.7 \\
B & $5.0 \pm 0.2$ & 4.3 & 0.8 \\
C & $7.2 \pm 0.2$ & 5.5 & 0.7 \\
D & $0.2 \pm 0$ & 0.1 & \\
E & $0.1 \pm 0$ & 0.1 & \\
\hline & & & \\
\hline
\end{tabular}

$\mathrm{A}-\mathrm{KOH} / 25{ }^{\circ} \mathrm{C} / 24 \mathrm{~h}, \mathrm{~B}-\mathrm{KOH} / 25{ }^{\circ} \mathrm{C} / 48 \mathrm{~h}, \mathrm{C}-\mathrm{KOH} / 121{ }^{\circ} \mathrm{C} / 1 \mathrm{~h}, \mathrm{D}-$ glycerol $(20 \%) / 121{ }^{\circ} \mathrm{C}, \mathrm{E}-$ glycerol $(40 \%) / 121{ }^{\circ} \mathrm{C} / 1 \mathrm{~h}$. Xylan conversion to xylose in pretreated biomass at 5\% DM using cellulase (Cellic Ctec2) and xylanase (Cellic Htec2) loadings of 11.14 FPU and 0.44 FPU/g TS, respectively. Xylan conversion to xylose is expressed as $\mathrm{g}$ xylose released in enzymatic hydrolysis per $100 \mathrm{~g}$ xylan in pretreated solids, multiplied by the hydration factor of xylose $(0.88)$. 
Table 6

Ethanol concentration, conversion efficiency and yield

\begin{tabular}{|c|c|c|c|}
\hline $\begin{array}{l}\text { Pretreatment } \\
\text { condition }\end{array}$ & $\begin{array}{c}\text { Final ethanol } \\
\text { concentration, } \\
\text { g/L in fermentation }\end{array}$ & $\begin{array}{l}\text { Conversion efficiency } \\
\text { (\% theoretical ethanol } \\
\text { conversion), } \\
\text { g/100 g of potential ethan } \\
\text { from pretreated biomas }\end{array}$ & $\begin{array}{l}\text { Ethanol yield, } \\
\text { g/100 g DM of } \\
\text { untreated material }\end{array}$ \\
\hline & \multicolumn{3}{|c|}{ Bamboo } \\
\hline A & $2.4 \pm 0.1$ & 10.5 & $2.1 \pm 0.1$ \\
\hline B & $2.3 \pm 0.4$ & 10.5 & $2.1 \pm 0.4$ \\
\hline $\mathrm{C}$ & $7.8 \pm 2.4$ & 28.9 & $5.8 \pm 2.4$ \\
\hline $\mathrm{D}$ & $0.3 \pm 0.2$ & 1.3 & $0.3 \pm 0.2$ \\
\hline $\mathrm{E}$ & $0.3 \pm 0.1$ & 1.5 & $0.3 \pm 0.1$ \\
\hline \multicolumn{4}{|c|}{ Rubber } \\
\hline B & $4.2 \pm 0.2$ & 18.6 & $3.7 \pm 0.2$ \\
\hline $\mathrm{C}$ & $7.4 \pm 0.2$ & 33.4 & $5.8 \pm 0.2$ \\
\hline $\mathrm{D}$ & $2.2 \pm 1.1$ & 14.5 & $2.2 \pm 1.1$ \\
\hline $\mathrm{E}$ & $1.5 \pm 0.3$ & 9.6 & $1.4 \pm 0.3$ \\
\hline \multicolumn{4}{|c|}{ Elephant grass } \\
\hline A & $5.9 \pm 0.9$ & 26.8 & $4.1 \pm 0.9$ \\
\hline B & $5.4 \pm 1.8$ & 24.8 & $4.0 \pm 1.8$ \\
\hline $\mathrm{C}$ & $16.4 \pm 1.1$ & 53.2 & $9.8 \pm 1.2$ \\
\hline $\mathrm{D}$ & $2.0 \pm 0.3$ & 10.2 & $2.0 \pm 0.3$ \\
\hline $\mathrm{E}$ & $1.9 \pm 0.5$ & 10.2 & $1.9 \pm 0.5$ \\
\hline A & $1.3 \pm 0.5$ & 6.9 & $1.0 \pm 0.5$ \\
\hline B & $1.5 \pm 0.2$ & 8.7 & $1.3 \pm 0.2$ \\
\hline $\mathrm{C}$ & $2.2 \pm 0.6$ & 11.1 & $1.7 \pm 0.6$ \\
\hline $\mathrm{D}$ & $0.4 \pm 0.1$ & 2.3 & $0.4 \pm 0.1$ \\
\hline E & $0.3 \pm 0.1$ & 2.1 & $0.3 \pm 0.1$ \\
\hline
\end{tabular}




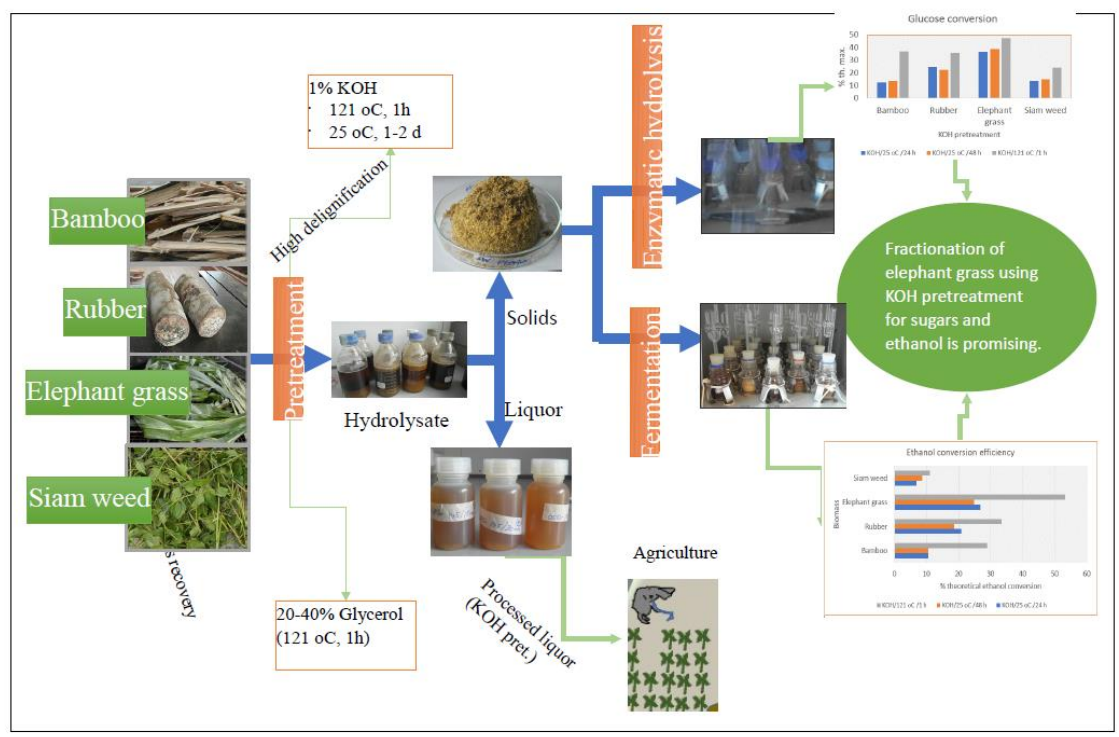

\section{Graphical abstract}




\section{Highlights}

- Mild $\mathrm{KOH}$ and glycerol pretreatment $\left(25-121^{\circ} \mathrm{C}\right)$ of four biomass were studied.

- Highest delignification (67.5\%) was observed for elephant grass.

- Glucan conversion (47.3\%) was highest for the grass under alkaline conditions.

- Xylan conversion was $46.7-58.6 \%$ for $\mathrm{KOH}$ pretreatment at $121^{\circ} \mathrm{C}$.

- $\mathrm{KOH}$ pretreatment gave the highest ethanol conversion on the grass at $53.2 \%$. 
$\mathrm{KOH}$ pretreated samples
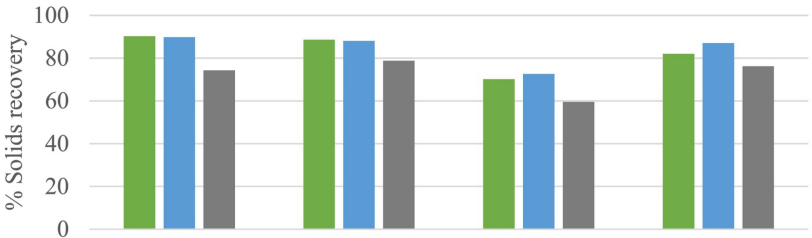

Bamboo wood

Rubber wood

Elephant grass

Siam weed

Biomass

$\because \mathrm{A} \| \mathrm{B}=\mathrm{C}$

Glycerol pretreated samples
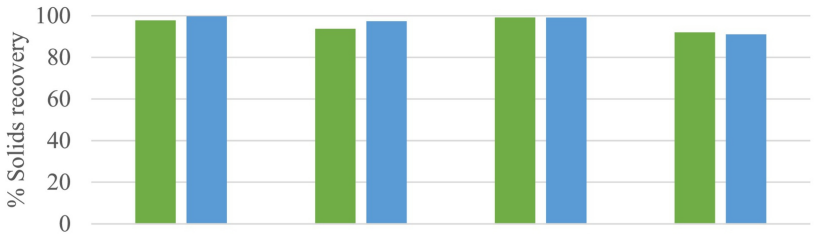

Bamboo wood

Elephant grass

Biomass

$\pm \mathrm{D}=\mathrm{E}$

Figure 1 
Bamboo
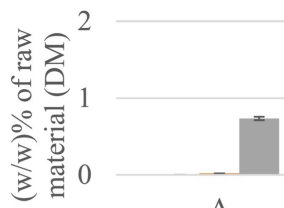

A

B

\section{$\mathrm{C}$}

- Lactic acid $\quad$ Formic acid $\quad$ Acetic acid

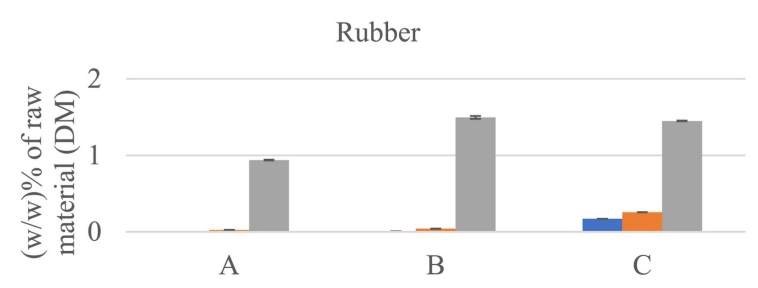

- Lactic acid $\quad$ Formic acid $\quad$ Acetic acid
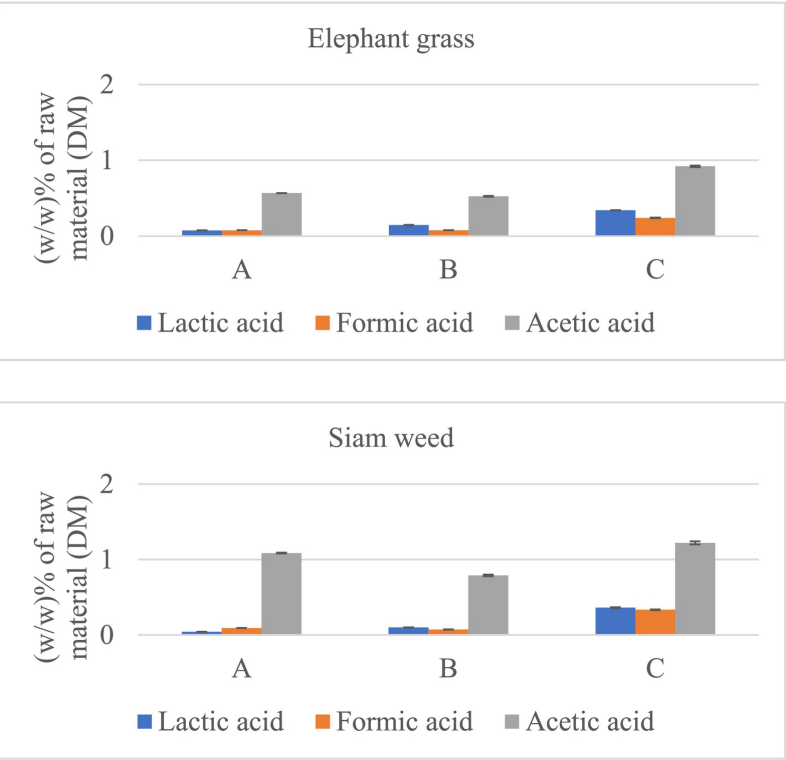

Figure 2 

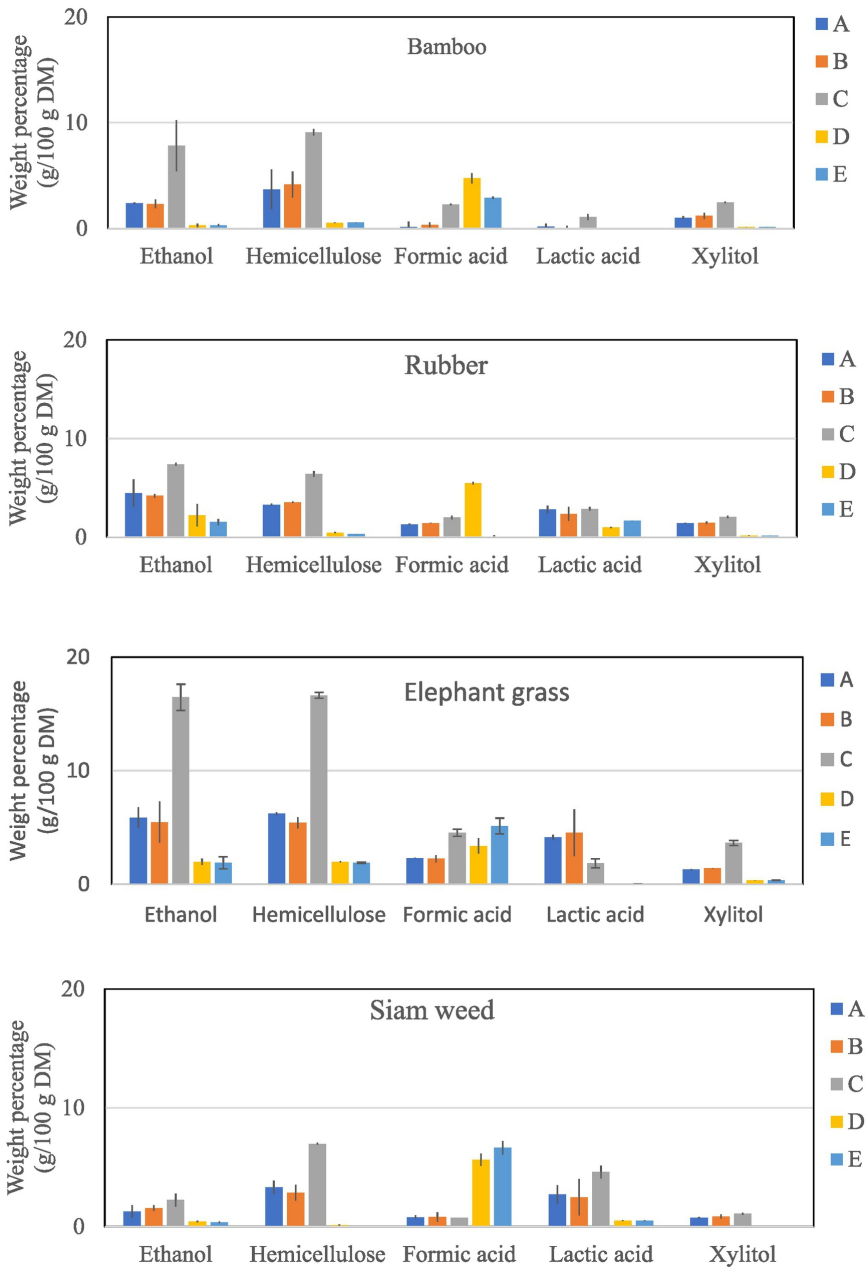

Figure 3 